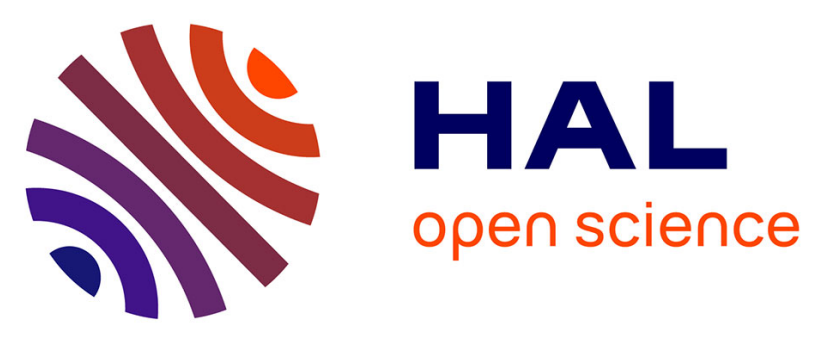

\title{
Zinc supplementation attenuates ethanol- and acetaldehyde-induced liver stellate cell activation by inhibiting reactive oxygen species (ROS) production and by influencing intracellular signaling
}

Agnieszka Szuster-Ciesielska, Krzysztof Plewka, Jadwiga Daniluk, Martyna Kandefer-Szerszeń

\section{To cite this version:}

Agnieszka Szuster-Ciesielska, Krzysztof Plewka, Jadwiga Daniluk, Martyna Kandefer-Szerszeń. Zinc supplementation attenuates ethanol- and acetaldehyde-induced liver stellate cell activation by inhibiting reactive oxygen species (ROS) production and by influencing intracellular signaling. Biochemical Pharmacology, 2009, 78 (3), pp.301. 10.1016/j.bcp.2009.04.009 . hal-00493516

\author{
HAL Id: hal-00493516 \\ https://hal.science/hal-00493516
}

Submitted on 19 Jun 2010

HAL is a multi-disciplinary open access archive for the deposit and dissemination of scientific research documents, whether they are published or not. The documents may come from teaching and research institutions in France or abroad, or from public or private research centers.
L'archive ouverte pluridisciplinaire HAL, est destinée au dépôt et à la diffusion de documents scientifiques de niveau recherche, publiés ou non, émanant des établissements d'enseignement et de recherche français ou étrangers, des laboratoires publics ou privés. 


\section{Accepted Manuscript}

Title: Zinc supplementation attenuates ethanol- and acetaldehyde-induced liver stellate cell activation by inhibiting reactive oxygen species (ROS) production and by influencing intracellular signaling

Authors: Agnieszka Szuster-Ciesielska, Krzysztof Plewka,

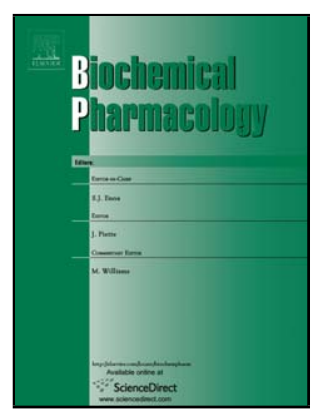
Jadwiga Daniluk, Martyna Kandefer-Szerszeń

PII: S0006-2952(09)00295-0

DOI: doi:10.1016/j.bcp.2009.04.009

Reference: BCP 10149

To appear in: $\quad B C P$

Received date: $\quad$ 4-2-2009

Revised date: $\quad 9-4-2009$

Accepted date: $\quad 9-4-2009$

Please cite this article as: Szuster-Ciesielska A, Plewka K, Daniluk J, KandeferSzerszeń M, Zinc supplementation attenuates ethanol- and acetaldehyde-induced liver stellate cell activation by inhibiting reactive oxygen species (ROS) production and by influencing intracellular signaling, Biochemical Pharmacology (2008), doi:10.1016/j.bcp.2009.04.009

This is a PDF file of an unedited manuscript that has been accepted for publication. As a service to our customers we are providing this early version of the manuscript. The manuscript will undergo copyediting, typesetting, and review of the resulting proof before it is published in its final form. Please note that during the production process errors may be discovered which could affect the content, and all legal disclaimers that apply to the journal pertain. 
Zinc supplementation attenuates ethanol- and acetaldehyde-induced liver stellate cell activation by inhibiting reactive oxygen species (ROS) production and by influencing intracellular signaling

Agnieszka Szuster-Ciesielska ${ }^{a^{*}}, K$ rzysztof Plewka ${ }^{a}$, Jadwiga Daniluk ${ }^{b}$, Martyna KandeferSzerszeń $^{\mathrm{a}}$

${ }^{\mathrm{a}}$ Department of Virology and Immunology, Maria Curie-Skłodowska University, Akademicka 19, 20-033 Lublin, Poland,

mail: Krzysztof Plewka: hurin22@wp.pl,

Martyna Kandefer-Szerszeń: kandem@poczta.umcs.lublin.pl

${ }^{\mathrm{b}}$ Department and Clinic of Gastroenterology, University Medical School, Jaczewskiego 8, 20950 Lublin, Poland, mail: j.daniluk@wp.pl

Running title: Zinc inhibits activation of liver stellate cells

* corresponding author:

Agnieszka Szuster-Ciesielska

Department of Virology and Immunology

Maria Curie-Skłodowska University

Akademicka 19, 20-033 Lublin, Poland

E-mail: szustera@hektor.umcs.lublin.pl

Tel./fax: +048 815375959 


\section{Abstract}

Background/Aims. Zinc has been reported to prevent and reverse liver fibrosis in vivo; however, the mechanisms of its action are poorly understood. We therefore aimed to determine the antifibrotic potential of zinc.

Methods. Assessed was the influence of preincubation of rat $\mathrm{HSCs}$ with $30 \mu \mathrm{M} \mathrm{ZnCl} 2$ on ethanol- (in the presence of 4-methyl pyrazole (4-MP)) or acetaldehyde-induced toxicity; apoptosis; migration, expression of smooth muscle $\alpha$-actin ( $\alpha$-SMA) and procollagen I; release of reactive oxygen species (ROS), tumor necrosis factor- $\alpha$ (TNF- $\alpha$ ), tumor growth factor- $\beta 1$ (TGF- $\beta 1$ ); metalloproteinase-2 (MMP-2) and tissue inhibitors of metalloproteinases (TIMPs) production. Intracellular signals such as nuclear factor- $\kappa \mathrm{B}(\mathrm{NF \kappa B}), \mathrm{C}-\mathrm{Jun} \mathrm{N}-$ terminal kinase (JNK) and p38 mitogen-activated protein kinase (p38 MAPK) induced by ethanol and its metabolite was also assessed.

Results. $30 \mu \mathrm{M}$ zinc protected HSCs against ethanol and acetaldehyde toxicity and inhibited their apoptosis. Zinc inhibited the production of ROS by HSCs treated with ethanol and acetaldehyde and inhibited their migration. Zinc also inhibited ethanol- and acetaldehydeinduced TGF- $\beta 1$ and TNF- $\alpha$ production. Zinc down-regulated ethanol- and acetaldehydeinduced production of TIMP-1 and TIMP-2 and decreased the activity of MMP-2. In ethanoland acetaldehyde-induced HSCs, zinc inhibited the activation of the p38 MAPK as well as the JNK transduction pathways and phosphorylation of IкB and Smad3.

Conclusion. The results indicated that zinc supplementation inhibited ethanol- and acetaldehyde-induced activation of HSCs on different levels, acting as an antioxidant and inhibitor of MAPK, TGF- $\beta$ and $\mathrm{NF} \kappa \mathrm{B} / \mathrm{I} \kappa \mathrm{B}$ transduction signaling. The remarkable inhibition of several markers of HCS activation makes zinc a promising agent for antifibrotic combination therapies. 
Key words: liver stellate cells, zinc, cytokines, MAPK, NFאB

\section{Introduction}

Liver fibrosis is caused by a variety of etiologic agents, including chronic viral hepatitis, alcohol toxicity, autoimmune disease, and hereditary metabolic disorders. For all of these diseases, there is a common pathologic mechanism that leads to fibrosis: the generation and proliferation of smooth muscle $\alpha$-actin ( $\alpha$-SMA)-positive myofibroblasts of periportal and perisinusoidal origin that arise as a consequence of the activation of hepatic stellate cells (HSCs). HSCs exist in the normal liver as quiescent retinoid-storing cells, which in response to injury activate to become proliferative, profibrogenic cells [1,2]. This event can be recapitulated in a culture model in which isolated HSCs are cultured on plastic in serumcontaining media. The activated HSCs are a rich source of type I and III fibrillar collagen and also secrete high levels of the tissue inhibitor of metalloproteinase 1 (TIMP-1) [3]. Many of the morphological and metabolic changes associated with HSC activation during fibrogenesis in vivo are also observed in HSCs grown in culture on plastic. These changes include the expression of new receptors, such as platelet-derived growth factor $\beta$ receptors 1 and 2. Other receptors, such as the receptor for insulin-like growth factor 1 and endothelin are present on both quiescent and activated HSCs [4,5]. Several soluble factors, including growth factors, cytokines, chemokines and oxidative stress products, play a role in the activation of HSCs. Activation of HSCs is associated with the sequential expression of several key cytokines and their surface receptors, including transforming growth factor $\beta$ (TGF- $\beta$ ) and its receptors [6]. Exogenous expression of TGF- $\beta$ in the liver induces liver fibrosis, and blockade of TGF- $\beta$ signaling by multiple methods prevents progression of liver fibrosis in experimental animals [7]. TGF- $\beta$ downstream signaling is mediated by Smad 2 and Smad 3, which are structurally 
similar but functionally distinct. They are differentially activated by TGF- $\beta$ in quiescent and activated HSCs and play different roles in HSC function $[8,9]$.

The development of liver fibrosis in alcoholics has been linked to the oxidation of ethanol to the highly active compound acetaldehyde. At concentrations that have been detected in hepatic venous blood during alcohol consumption, acetaldehyde stimulates type I collagen synthesis and gene transcription in cultured rat and human HSCs through protein kinase C (PKC) activation [10]. Acetaldehyde has also been shown to increase NFkB (p65) and its binding to the $\alpha_{2}(\mathrm{I})$ collagen promotor [11] by a mechanism dependent on the accumulation of $\mathrm{H}_{2} \mathrm{O}_{2}[12,13,14]$. CYP2E1 is an important source of reactive oxygen species (ROS) in alcohol-induced injury and fibrosis, generating superoxide $\left(\mathrm{O}_{2}{ }^{-}\right)$and hydrogen peroxide $\left(\mathrm{H}_{2} \mathrm{O}_{2}\right)$. It has been detected that inhibition of CYP2E1 activity by diallylsulfide (DAS) prevents induction of collagen I gene expression in rat stellate cells overexpressing CYP2E1 [15]. Oxidative stress also activates the c-Jun $\mathrm{NH}_{2}$-terminal kinase (JNK), a protein which regulates secretion of proinflammatory cytokines by cultured HSCs $[16,17]$.

Matrix metalloproteinases (MMP), a family of zinc metallo-endopeptidases, are promptly expressed by HSCs in response to diverse hepatic toxins. In vitro experiments have demonstrated the role of MMPs in the activation of HSCs. Also proliferation of HSCs was promoted by pericellular collagen I proteolysis acting via $\alpha v \beta 3$ integrins [18]. Conversely, MMPs may also contribute to regression of liver fibrosis through cleavage of the fibrillar ECM and promotion of apoptosis among the activated HSCs. Thus MMPs play dual roles in liver fibrosis, depending on the timing [19].

Zinc is an essential nutrient that is necessary for a broad range of biological activities. To date, more than 300 zinc-containing enzymes have been identified. Serum and hepatic zinc concentrations are decreased in chronic liver diseases, and zinc depletion has been suggested as a cause of hepatic fibrosis [20,21]. Zinc supplementation has been shown to have a 
favorable effect on fibrosis in vivo and in vitro [22,23]; however, the mechanisms of the antifibrotic effect of zinc are not fully understood. In a pilot study in vivo with oral zinc supplementation, down-regulation of TIMP-1 was detected in sera of patients whose zinc levels had been raised [23]. As TIMP-1 has been described [24] to have an antiapoptotic effect on activated HSCs, such a decrease in its production can be beneficial for the resolution of liver fibrosis. It has also been detected that in zinc-deficient HSCs, depletion of intracellular glutathione levels triggers a progression of collagen synthesis [21].

The aim of this study was to investigate the effect of zinc supplementation on the viability, proliferation, apoptosis and activation of rat HSCs cultured in vitro. We also examined whether zinc influenced the production of some cytokines, MMPs, and TIMPs in ethanol- and acetaldehyde-activated HSCs. To assess the mechanisms of zinc influence on HSC activation, we examined whether zinc changed the intracellular signaling involved in HSC activation, such as TGF- $\beta$-inducing signaling, NFkB, JNK and p38 MAPK activation.

\section{Materials and Methods}

\subsection{Cell cultures}

A moderately activated rat liver stellate cell line CFSC-2G was kindly provided by Dr Marcos Rojkind (Department of Clinical Investigation, Walter Reed Army Medical Center, Washington). CFSC-2G cells were cultured in Eagle's Medium (MEM), supplemented with $5 \%$ heat-inactivated fetal calf serum (FCS), 1\% nonessential amino acids (NEAA), and 1\% Antibiotic-Antimycotic, pH 7.4. The cells were seeded in tissue culture plates (Falcon, Bedford, MA, USA) and incubated at $37^{\circ} \mathrm{C}$ in a humidified atmosphere of $5 \% \mathrm{CO}_{2}$. CFSC-2G cells were subcultured twice a week by trypsinization in a $0.25 \%$ trypsin-EDTA solution after washing with Ca-Mg-free saline. The culture media, antibiotics, $0.25 \%$ trypsin-EDTA, FCS 7 
and NEAA were obtained from Sigma-Aldrich (Steinheim, Germany). In some experiments, Hanks' Balanced Salt Solution (HBSS) (Sigma-Aldrich) was used.

2.2. The influence of different ethanol and acetaldehyde concentrations on CFSC-2G cell viability after preincubation with $\mathrm{ZnCl}_{2}$.

CFSC-2G cells were grown in 96-well plastic plates (Nunc, Roskilde, Denmark), 2 × $10^{5}$ cells/well, in Eagle's Medium (MEM) supplemented with 5\% FCS. After $24 \mathrm{~h}$ incubation, the medium was replaced with a fresh one with addition of $0.1 \% \mathrm{FCS}$ and $30 \mu \mathrm{M} \mathrm{ZnCl}{ }_{2}$ (Sigma). After another $24 \mathrm{~h}$ of incubation, different ethanol (100-500 $\mathrm{mM})$ or acetaldehyde $(0.5-3 \mathrm{mM})$ concentrations were added. Ethanol and acetaldehyde were purchased from Merck (Darmstad, Germany) and maintained as $1 \mathrm{M}$ stock solutions. The cells treated with ethanol or acetaldehyde were maintained in a humidified $\mathrm{CO}_{2}$-incubator at $37^{\circ} \mathrm{C}$ for $24 \mathrm{~h}$. The toxicity of those chemicals was determined by the 3-(4,5-dimethylthiazo-2-yl)-2,5-diphenyl-tetrazolium bromide (MTT) (Sigma) assay in which the yellow tetrazolium salt was metabolized by viable cells to purple formazan crystals. CFSC-2G cells were incubated for $3 \mathrm{~h}$ with the MTT solution $(5 \mathrm{mg} / \mathrm{ml})$. Formazan crystals were solubilized overnight in SDS buffer (10 SDS in $0.01 \mathrm{~N} \mathrm{HCl}$ ), and the product was quantified spectrophotometrically by measuring absorbance at $570 \mathrm{~nm}$ wavelength using an E-max Microplate Reader (Molecular Devices Corporation, Menlo Park, CA, USA). Data were presented as \% of control cell viability. According to the data including in Fig. 1 for further experiments, three ethanol concentrations $(5,10$ and 50 $\mathrm{mM})$ and two concentrations of acetaldehyde $(75$ and $175 \mu \mathrm{M})$ were chosen because they did not exhibit any toxicity for CFSC-2G cells.

\subsection{Cell proliferation assay.}

2.3.1. 3-(4,5-dimethylthiazo-2-yl)-2,5-diphenyl-tetrazolium bromide (MTT) assay 
CFSC-2G cells were grown in 96-well plastic plates (Nunc, Roskilde, Denmark), $5 \times 10^{3}$ cells/well, in Eagle's Medium (MEM) supplemented with 5\% FCS for $24 \mathrm{~h}$. Then the medium was replaced with a fresh one with addition of ethanol $(0-500 \mathrm{mM})$, acetaldehyde $(0-500 \mu \mathrm{M})$ or zinc $(1-100 \mu \mathrm{M})$. After $96 \mathrm{~h}$ incubation at $37^{\circ} \mathrm{C}$ in a humidified atmosphere of $5 \% \mathrm{CO}_{2}$, the MTT assay was performed, and the data were presented as \% of control cell viability.

\subsubsection{BrdU assay}

CFSC-2G were seeded at a density $5 \times 10^{3}$ per well in 96-well plates and cultured in 5\% FCSMEM for $24 \mathrm{~h}$. Then the medium was replaced with a fresh one with addition of ethanol (0$500 \mathrm{mM})$, acetaldehyde $(0-500 \mu \mathrm{M})$ or zinc $(1-100 \mu \mathrm{M})$. After $96 \mathrm{~h}$ incubation at $37^{0} \mathrm{C}$ in a humidified atmosphere of $5 \% \mathrm{CO}_{2}$, the cells were exposed to $10 \mu \mathrm{M}$ BrdU for a 2-h labeling period. The incorporation of BrdU was measured by a colorimetric BrdU cell proliferation ELISA according to the manufacturer's instructions (Roche Diagnostics GmbH, Mannheim, Germany).

\subsection{Migration assay}

2.4.1. Cell migration was assessed using an in vitro wound closure assay

CFSC-2G cells were plated at $6 \times 10^{5}$ on 4 -cm culture dishes (Nunc) in 5\% FCS-MEM for 24 h. Then one linear wound was scraped in each well with a sterile pipette tip (P300). The wounded monolayers were rinsed twice with culture medium to remove all cellular debris, and the medium was replaced with a fresh one with addition of $0.1 \%$ FCS-MEM and, in some cultures, also $30 \mu \mathrm{M} \mathrm{ZnCl}$. After $24 \mathrm{~h}$ incubation, $50 \mathrm{mM}$ ethanol or $175 \mu \mathrm{M}$ acetaldehyde was added into wells with or without $\mathrm{ZnCl}_{2}$. Control cells were cultured in $0.1 \%$ FCS-MEM. The number of cells that had migrated into the wounded area after $24 \mathrm{~h}$ was estimated in control and cultures treated with ethanol or acetaldehyde which were pretreated or not with $30 \mu \mathrm{M} \mathrm{ZnCl}$. Plates were stained with the May-Grünwald-Giemsa method. The observation 
was performed under an Olympus BX51 System Microscope (Olympus Optical, Tokyo, Japan), and micrographs were prepared using the analySIS software (Soft Imaging System $\mathrm{GmbH}$, Münster, Germany). Cells which had migrated to the wounded areas were counted on micrographs, and the results were expressed as a mean number of cells which had migrated to 100 selected wounded areas taken from three micrographs.

\subsubsection{Cell migration through Matrigel.}

To mimic the microenvironment of the space of Disse, insert membranes with 8 - $\mu$ m pores (6.5 mm Transwell plates, Costar) were covered with Matrigel (Sigma, E1270) $\left(100 \mu \mathrm{g} / \mathrm{cm}^{2}\right.$ ), which was prepared according to the manufacturer's instructions. CFSC-2G cells $(2 \mathrm{x}$ $10^{4} /$ well) were added into the upper chamber, and were cultured in MEM supplemented with $0.1 \%$ FCS. The bottom wells of the chamber were filled with the same medium with or without $30 \mu \mathrm{M} \mathrm{ZnCl}_{2}$. After $24 \mathrm{~h}$ incubation at $37^{\circ} \mathrm{C}$ in a humidified atmosphere of $5 \% \mathrm{CO}_{2}$, acetaldehyde (at a final concentration $175 \mu \mathrm{M}$ ) was added into part of the bottom wells. The Transwell plates were incubated for another $24 \mathrm{~h}$ to allow possible migration of CFSC-2G cells through the membrane into the lower chamber. The chambers were then immersed in $100 \%$ methanol (Sigma) for 1 min for fixation, and all cells were then stained for 5 min with hematoxylin (Sigma). The cells remaining on the top surface of the membrane were completely removed with a cotton swab, and the membrane was removed from the chamber and mounted on a glass slide. The number of infiltrating cells was counted in ten selected regions and determined by the mean count. The experiments were repeated three times.

\subsection{Apoptosis measurement}

2.5.1. Preparation of CFSC-2G cells for caspase 3 activity assay

For the measurement of caspase 3 activity, CFSC-2G were grown in 6-well plastic plates ( $4 \mathrm{x}$ $10^{5}$ cells $/ \mathrm{ml}, 5 \mathrm{ml} /$ well) in $5 \%$ FCS-MEM for $24 \mathrm{~h}$ in a humidified $\mathrm{CO}_{2}$-incubator at $37^{\circ} \mathrm{C}$. 
Then the medium was replaced with fresh $0.1 \%$ FCS-MEM with or without $\mathrm{ZnCl}_{2}$ (final concentration $30 \mu \mathrm{M}$ ). The next day, $50 \mathrm{mM}$ ethanol or $175 \mu \mathrm{M}$ acetaldehyde were added into the wells with or without $\mathrm{ZnCl}_{2}$, and the wells were incubated for another $18 \mathrm{~h}$ at $37^{\circ} \mathrm{C}$. Each sample was prepared in duplicate, with or without the addition of a caspase inhibitor (ZVAD-FMK, final concentration $20 \mu \mathrm{M}$ ) (Promega, Madison, WI). Control wells were incubated without the addition of zinc, ethanol or acetaldehyde. After washing with Ca-Mgfree saline, the cells were scraped with a rubber policeman, transferred into Eppendorf tubes with Lysis Buffer $\left(25 \mu 1\right.$ of cold Lysis Buffer per $1 \times 10^{6}$ cells). The cell lysate was incubated on ice for $10 \mathrm{~min}$ and then centrifuged at $10,000 \mathrm{x} \mathrm{g}$ for $1 \mathrm{~min}$.

\subsubsection{Caspase 3 enzymatic assay}

The enzyme activity was determined with a Caspase 3 Colorimetric Assay kit (R\&D Systems Inc., Minneapolis, MN). The enzymatic reaction was carried out in 96-well flat bottom microplates. $50 \mu \mathrm{l}$ of cell lysates (derived from $2 \times 10^{6}$ cells) were tested in duplicate experiments by measuring the proteolytic cleavage of DEVD-pNA, a colorimetric substrate specific for caspase 3. Recombinant caspase 3 (R\&D Systems Inc., Minneapolis, MN) was used as positive control. After 2 hours of incubation at $37^{\circ} \mathrm{C}$, color development was measured with a microtiter plate reader (E-max, Molecular Devices Co, Menlo Park, CA, USA) using $405 \mathrm{~nm}$ wavelength light. Caspase 3 activity in the treated cells was compared to that in the untreated cells, and expressed as a fold change.

2.6. Treatment of CFSC-2G cells with ethanol in the presence of cytochrome P4502E1 or ADH inhibitors

CFSC-2G cells were grown in 96-well plastic plates (Nunc, Roskilde, Denmark), $2 \times 10^{4}$ cells/well with nontoxic concentrations of ethanol metabolism inhibitors: cytochrome P4502E1 - 2 mM DAS (Sigma) or ADH - 2 mM 4-MP (Sigma) . After 24 h of incubation, an 
oxygen burst was induced by ethanol at a concentration of $50 \mathrm{mM}$, and the production of superoxide anion was measured by the cytochrome c reduction assay [25].

2.7. Treatment of CFSC-2G cells with ethanol or acetaldehyde after preincubation with 30 $\mu \mathrm{M} \mathrm{ZnCl} 2$

CFSC-2G cells were grown in 6 -well plastic plates $\left(4 \times 10^{5}\right.$ cells $\left./ \mathrm{ml}, 5 \mathrm{ml} / \mathrm{well}\right)$ in $5 \%$ FCS-MEM for $24 \mathrm{~h}$ in a humidified $\mathrm{CO}_{2}$-incubator at $37^{\circ} \mathrm{C}$. Then the medium was replaced with fresh $0.1 \%$ FCS-MEM with or without $2 \mathrm{mM} 4$-MP and with or without $30 \mu \mathrm{M} \mathrm{ZnCl} \mathrm{Zn}_{2}$ for another $24 \mathrm{~h}$ at $37^{\circ} \mathrm{C}$. Then the inductors, ethanol at different concentrations (final concentrations 5,10 or $50 \mathrm{mM}$ ) or acetaldehyde (final concentration $175 \mu \mathrm{M}$ ), were added into wells. The wells, to which ethanol was added had been supplemented with $2 \mathrm{mM}$ 4-MP. Plates were prepared in duplicate; a) after 20 min of incubation and washing twice with PBS, the cells were collected for Western blot analysis of phospho- and total NFkB, phospho- and total $\mathrm{I} \kappa \mathrm{B}$, phospho- and total $\mathrm{JNK}$, and phospho- and total p38 b) after $24 \mathrm{~h}$ of incubation, the cultures were washed twice with PBS and the cells were harvested for Western blot analysis of $\alpha$-SMA, procollagen I, TIMP-1, TIMP-2, MMP-13, and phospho- and total Smad 3.

2.8. Treatment of CFSC-2G cells with ethanol or acetaldehyde in the presence of the protein kinase $\mathrm{C}$ inhibitor and with or without preincubation with $30 \mu \mathrm{M} \mathrm{ZnCl}_{2}$

CFSC-2G cells were grown in 6 -well plastic plates $\left(4 \times 10^{5}\right.$ cells $\left./ \mathrm{ml}, 5 \mathrm{ml} / \mathrm{well}\right)$ in $5 \%$ FCS-MEM for $24 \mathrm{~h}$ in a humidified $\mathrm{CO}_{2}$-incubator at $37^{\circ} \mathrm{C}$. Then the medium was replaced with fresh $0.1 \%$ FCS-MEM with $2 \mathrm{mM} 4-\mathrm{MP}$ and with or without $1 \mu \mathrm{M}$ calphostin $\mathrm{C}$ (a protein kinase $\mathrm{C}$ inhibitor) (Sigma) or without $30 \mu \mathrm{M} \mathrm{ZnCl}$ for another $24 \mathrm{~h}$ at $37^{0} \mathrm{C}$. Then the inductors, ethanol at different concentrations (final concentrations 5, 10 or $50 \mathrm{mM}$ in wells with 4-MP) or acetaldehyde (final concentration $175 \mu \mathrm{M}$ ), were added into wells. After $24 \mathrm{~h}$ 
of incubation, the cultures were washed twice with PBS and the cells were harvested for Western blot analysis of $\alpha$-SMA.

2.9. Measurement of superoxide anion $\left(\mathrm{O}_{2}^{-}\right)$production by cytochrome c reduction assay [25]

CFSC-2G cells were grown in 96-well plastic plates $\left(2 \times 10^{4}\right.$ cells/well) for $24 \mathrm{~h}$ at $37^{0} \mathrm{C}$ in a humidified atmosphere of $5 \% \mathrm{CO}_{2}$. Then, the cultures were washed twice with HBSS and the culture medium was replaced with fresh $0.1 \%$ FCS-MEM with or without $30 \mu \mathrm{M} \mathrm{ZnCl}$. The next day, an assay for superoxide anion was performed. Briefly, HBSS (207.5 $\mu 1), 12.5 \mu 1$ of cytochrome c solution in HBSS (final concentration $75 \mu \mathrm{M}$ ), $5 \mu \mathrm{l}$ of either SOD solution (final concentration $60 \mathrm{U} / \mathrm{ml}$ ) or $5 \mu \mathrm{HBSS}$, and $25 \mu \mathrm{l}$ ethanol solution in HBSS (final concentration of 5,10 or $50 \mathrm{mM}$ ) or $25 \mu$ lacetaldehyde solution in HBSS (final concentration of 75 or $175 \mu \mathrm{M}$ ) were added into each well on a 96-well plate. Also control wells were used, where cells were incubated without ethanol or acetaldehyde. The microplate was incubated at $37^{0} \mathrm{C}$ for $60 \mathrm{~min}$ and transferred to the microplate reader. The absorbance values at $550 \mathrm{~nm}$ (the differences in OD between samples with and without SOD) were converted to nanomoles of $\mathrm{O}_{2}^{-}$based on the extinction coefficient of cytochrome c: $\Delta \mathrm{E}_{550}=21 \times 10^{3} \mathrm{M}^{-1} \mathrm{~cm}^{-1}$. The results were expressed as nanomoles of $\mathrm{O}_{2}^{-}$per $1 \times 10^{6}$ cells per $60 \mathrm{~min}$. All chemicals were purchased from Sigma -Aldrich.

2.10. Measurement of hydrogen peroxide $\left(\mathrm{H}_{2} \mathrm{O}_{2}\right)$ production [26]

HepG2 cells were grown in 96-well plastic plates $\left(4 \times 10^{4}\right.$ cells/well) with or without 30 $\mu \mathrm{M} \mathrm{ZnCl}$. After $24 \mathrm{~h}$ incubation at $37^{\circ} \mathrm{C}$, the cultures were washed twice with HBSS, and HBSS (100 $\mu \mathrm{l} /$ well) with an addition of ethanol (final concentration of $50 \mathrm{mM}$ ) or acetaldehyde (final concentration of $175 \mu \mathrm{M}$ ) for $60 \mathrm{~min}$ at $37^{\circ} \mathrm{C}$ into wells was added. In control wells, cells were incubated without ethanol or acetaldehyde. Those wells were washed 
twice with HBSS and a measurement of intracellular hydrogen peroxide was performed. The assay was based on horseradish-dependent peroxidation (HRPO) of phenol red by $\mathrm{H}_{2} \mathrm{O}_{2}$ leading to the formation of a compound that exhibited absorbance at $600 \mathrm{~nm}$. Briefly, the cells were covered with $100 \mu \mathrm{l} /$ well of the assay solution, which was prepared on the day of the experiment and consisted of HBSS, phenol red (Sigma, final concentration of $0.56 \mathrm{mM}$ ), HRPO (Serva, Heidelberg, Germany, final concentration of $20 \mathrm{U} / \mathrm{ml}$ ). Additionally, 10 $\mu \mathrm{l} /$ well of $1 \mathrm{~N} \mathrm{NaOH}$ was added. After 3 min of incubation, the plate was read at $600 \mathrm{~nm}$ in the microplate reader. The results were expressed as nanomoles $\mathrm{H}_{2} \mathrm{O}_{2}$ per $10^{6}$ cells per 60 min based on the phenol red extinction coefficient $\left(\Delta \mathrm{E}_{600}=19.8 \times 10^{3} \mathrm{M}^{-1} \mathrm{~cm}^{-1}\right)$.

\subsection{TNF- $\alpha$, TGF- $\beta$, MMP-2 and TIMP-1 assay}

CFSC-2G cells were cultured, in duplicate, in 24-well plastic plates (Nunc) at a density of $2 \times 10^{5}$ cells $/ \mathrm{ml} /$ well in 5\% FCS-MEM with or without $2 \mathrm{mM} \mathrm{4-MP} \mathrm{for} 24 \mathrm{~h}$ in a humidified $\mathrm{CO}_{2}$-incubator at $37^{0} \mathrm{C}$. Then the culture medium was replaced with $0.1 \%$ FCS-MEM containing or not $30 \mu \mathrm{M} \mathrm{ZnCl}$ and $2 \mathrm{mM} 4-\mathrm{MP}$. After $24 \mathrm{~h}$, a selected concentration of ethanol $(10$ or $50 \mathrm{mM})$ or acetaldehyde $(175 \mu \mathrm{M})$ was added. After incubation for another 24 $\mathrm{h}$ at $37^{\circ} \mathrm{C}, 5 \% \mathrm{CO}_{2}$, cell culture supernatants were collected, centrifuged and frozen immediately at $-80^{\circ} \mathrm{C}$ for a further TNF- $\alpha$, TGF- $\beta$, MMP-2 and TIMP- 1 assay. Culture supernatants were stored for no longer than 3 weeks. Rat TNF- $\alpha$, TGF- $\beta$, MMP-2 and TIMP1 present in the supernatants from CFSC-2G cells were measured by the ELISA method using kits from Bender MedSystems Diagnostics (TNF- $\alpha$ ) and R\&D Systems (TGF- $\beta$, MMP-2, TIMP-1). The kits contained a specific monoclonal antibody immobilized on a 96-well microtiter plate that bound TNF- $\alpha$, TGF- $\beta$, MMP-2 or TIMP-1 in the aliquot and a second enzyme-conjugated specific polyclonal antibody. Following several washings to remove unbound substances and antibodies, a substrate solution was added to the wells. Color 
development was stopped by sulfuric acid and the intensity of color was measured using a microtiter plate reader (E-max, Molecular Devices Co, Menlo Park, CA) at $450 \mathrm{~nm}$ (correction at $550 \mathrm{~nm}$ or $620 \mathrm{~nm}$ ). The detection limits were TNF- $\alpha>11.2 \mathrm{pg} / \mathrm{ml}$, TGF- $\beta>4.61$ $\mathrm{pg} / \mathrm{ml}, \mathrm{MMP}-2>0.16 \mathrm{ng} / \mathrm{ml}$ and TIMP-1 $>3.5 \mathrm{pg} / \mathrm{ml}$. Intra-assay variations were less than $10 \%$.

\subsection{Western blot analysis}

CFSC-2G cells were harvested and lyzed in RIPA buffer (50 mM Tris/ $\mathrm{HCl} \mathrm{pH} \mathrm{7.4,} 150$ $\mathrm{mM} \mathrm{NaCl}, 1 \%$ Triton X-100, $1 \mathrm{mM}$ EDTA, 1\% sodium deoxycholate, $0.1 \%$ SDS, $1 \mathrm{mM}$ $\mathrm{Na}_{3} \mathrm{VO}_{4}, 10 \mathrm{mM} \mathrm{NaF}$, and a protease inhibitor cocktail) and then centrifuged 10,000 rpm/5

min at $4^{0} \mathrm{C}$. Proteins were assayed using a BCA Protein Assay Kit (Pierce, Rockford, Ill, USA). For Western blot analysis, supernatants of RIPA cell lysates were solubilized in 5xSDS sample buffer (100 mM Tris/HCl pH 6.8, 25\% glycerol, 2\% SDS, $0.01 \%$ bromophenol blue, $3 \% \beta$-mercaptoethanol) and then boiled for $5 \mathrm{~min}$ at $100^{\circ} \mathrm{C}$. Equal amounts of the total cellular protein extract were separated on $10 \%$ SDS-PAGE at $200 \mathrm{~V}$ for 1 $\mathrm{h}$ under reducing conditions and electrotransferred in a semi-dry way to polyvinylidine difluoride membranes (PVDF, Millipore, Whatman) at $15 \mathrm{~V}$ for $15 \mathrm{~min}$ in a transfer buffer (47.8 mM Tris/HCl, $0.293 \%$ glycine, 20\% methanol), $\mathrm{pH} 8.1$. After blocking for $15 \mathrm{~min}$ at room temperature with $10 \%$ dried nonfat milk/TBS $/ 0.1 \%$ Tween 20 , the membranes were probed overnight at $+4^{0} \mathrm{C}$ with the primary antibody (diluted in $1 \% \mathrm{BSA} / \mathrm{TBS} / 0.1 \%$ Tween 20) as follows: rabbit polyclonal anti-procollagen type I (1:250, Santa Cruz Biotechnology), mouse monoclonal anti- $\alpha$-SMA $(1: 1000$, Sigma), mouse monoclonal anti- $\beta$-actin $(1: 4000$, Sigma), mouse monoclonal anti-TIMP-1 (1:500, R\&D Systems), rabbit monoclonal antiTIMP-2 (1:1000, Sigma), rabbit polyclonal anti-MMP-13 (1:200, USBiological), rabbit monoclonal anti-total Smad 3 (1:2000, Epitomics), rabbit monoclonal anti-phospho Smad 3 (1:1000, Epitomics), rabbit polyclonal anti-total NFkB p65 (1:2000, Chemicon), rabbit 


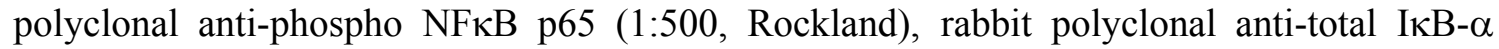
(1:2000, Sigma), mouse monoclonal anti-phospho IкB- $\alpha$ (1:1000, USBiological), rabbit polyclonal anti-total JNK (1:2000, Sigma), rabbit polyclonal anti-phospho JNK 1/2 (1:1000, Sigma), rabbit polyclonal anti-total p38 (1: 10 000, Sigma), and rabbit polyclonal antiphospho p38 (1:1000, Sigma). After repeated washing (TBS/0.1\% Tween 20), the membranes were incubated with the horseradish peroxidase-conjugated secondary (anti-rabbit or antimouse) antibody (1:4000, in $1 \% \mathrm{BSA} / \mathrm{TBS} / 0.1 \%$ Tween 20, Amersham Biosciences, Buckinghamshire, UK), and visualized using enhanced chemiluminescence reaction (ECL Western Blotting System, Amersham Biosciences, Buckinghamshire, UK). Protein bands were scanned, and the band intensities quantified using ImageJ densitometry software. All chemicals were purchased from Sigma-Aldrich.

\section{Statistical analysis}

Values are expressed as mean \pm S.D. The significance of differences was determined with the use of an analysis of variance (Statistica computer package). A number of statistical tests were used; these included the two-way ANOVA test with post-hoc Tukey's test and Wilcoxon's paired test for comparisons inside groups. P values $<0.05$ were considered to be significant.

\section{Results}

4.1. The influence of preincubation of $\mathrm{HSCs}$ with $30 \mu \mathrm{M} \mathrm{ZnCl}$ on their viability, proliferation and apoptosis after activation in vitro with ethanol and acetaldehyde

HSCs cultivated on plastic plates and silenced by a low $(0.1 \%)$ content of FCS in the medium were very resistant to ethanol and acetaldehyde toxicity. To demonstrate the effect of zinc supplementation to cell viability, the high concentrations of both ethanol and 
acetaldehyde were used. Ethanol at a $50 \mathrm{mM}$ concentration and acetaldehyde at an $0.5 \mathrm{mM}$ concentration exhibited no toxicity for HSCs in vitro. As can be seen from Fig 1., preincubation of HSCs with $30 \mu \mathrm{M}$ (non-toxic) $\mathrm{ZnCl}_{2}$ significantly inhibited the toxicity of ethanol and acetaldehyde. Moreover, the $100 \mathrm{mM}$ ethanol and $175 \mu \mathrm{M}$ acetaldehyde concentrations did not influence HSC growth as measured by the MTT method and the BrdU incorporation method (data not presented). However, $100 \mathrm{mM}$ ethanol caused 2-fold increase in level of cell apoptosis, as measured by caspase 3 activation, and zinc supplementation totally inhibited the apoptosis of HSCs nearly to the level of control (Table 1).

4.2. HSCs metabolize ethanol via the $\mathrm{ADH}$ and the C4502E1 pathways, and zinc supplementation inhibits ROS production

HSCs were incubated with ethanol and with inhibitors of ethanol metabolism, diallylsulfide (DAS) as an inhibitor of C4502E1 or 4-methylpyrazole (4-MP) as an inhibitor of alcohol dehydrogenase (ADH), used separately or in combination. Inhibition of ADH also caused an inhibition of superoxide anion production as did the use of the P4502E1 inhibitor. Both inhibitors used together inhibited the production of superoxide anion nearly totally (Fig. 2A). These results indicate that, in accordance with earlier publications, HSCs contain the enzymes of oxidative ethanol metabolism, including the $\mathrm{ADH}$ and $\mathrm{C} 4502 \mathrm{E} 1$ proteins $[27,28]$. When HSCs were preincubated with $30 \mu \mathrm{M} \mathrm{ZnCl}_{2}$ and thereafter with ethanol or acetaldehyde, a significant inhibition of superoxide anion production was observed (Fig 2B). When the level of hydrogen peroxide released from the cells was measured, $\mathrm{ZnCl}_{2}$ significantly inhibited its production induced by ethanol or acetaldehyde (Fig. 2C).

4.3. The influence of $\mathrm{ZnCl}_{2}$ supplementation on ethanol- and acetaldehyde-induced $\alpha$-SMA and procollagen I production. Zinc induces HSC quiescence 
HSCs were starved by incubation of the cells in a medium with $0.1 \%$ FCS and subsequently incubated with ethanol in the presence of 4-MP as an inhibitor of ADH or with acetaldehyde. The intracellular levels of $\alpha$-SMA and procollagen type I were estimated by Western blot. Ethanol and acetaldehyde induced the production of both $\alpha$-SMA and procollagen type I in a concentration-dependent manner (Fig. 3A and B). Preincubation with $\mathrm{ZnCl}_{2}$ significantly inhibited the expression of markers of HSC activation.

\subsection{The influence of $\mathrm{ZnCl}_{2}$ supplementation on $\mathrm{HSC}$ motility.}

HSC migration was assessed using the wound assay method. A cell monolayer was wounded with a pipette tip and the number of cells which had migrated into the wounded area after $24 \mathrm{~h}$ of incubation with ethanol in the presence of 4-MP or with acetaldehyde was estimated in control and in cultures preincubated with $30 \mu \mathrm{M} \mathrm{ZnCl}$. Zinc supplementation strongly inhibited the migratory activity of HSCs (Fig 4A). In another experiment, we examined the behavior of HSCs seeded on the top of Matrigel-coated filters to mimic the motility of HSCs in the liver. The lower compartment contained a medium with an addition of $175 \mu \mathrm{M}$ acetaldehyde. Zinc supplementation significantly inhibited acetaldehyde-induced migration of HSCs through the membrane coated with Matrigel (Fig. 4B).

4.5. Zinc supplementation down-regulates TGF- $\beta 1$ and TNF- $\alpha$ production in ethanol- or acetaldehyde-activated HSCs

Preincubation of HSCs with $30 \mu \mathrm{M} \mathrm{ZnCl} 2$ for $24 \mathrm{~h}$ caused a significant decrease in ethanol-induced TGF- $\beta 1$ and TNF- $\alpha$ production in the presence of 4-MP (Fig 5 A and B). Under similar experiment conditions, zinc supplementation also inhibited acetaldehydeinduced TGF- $\beta 1$ and TNF- $\alpha$ production (Fig $5 \mathrm{C}$ and D). 
4.6. Effect of zinc supplementation on metalloproteinase and TIMP production in ethanoland acetaldehyde-activated HSCs

The influence of preincubation of HSCs with $30 \mu \mathrm{M} \mathrm{ZnCl} 2$ on the production of MMP-2 and MMP-13 was examined. When total production of MMP-2 was examined by the ELISA method, zinc significantly decreased ethanol-induced production of this metalloproteinase (Fig 6A and B). Zinc supplementation did not influence the activity of MMP-13 in rat HSCs incubated with ethanol or acetaldehyde (Fig 7 A and B). In Western blot analysis, two forms of MMP-13, proMMP-13 and its activated form, were detected. Ethanol, independently of the concentration used, did not influence the production of proMMP-13 or its activated form. Acetaldehyde, in turn, significantly inhibited the amounts of activated MMP-13. Zinc did not influence its activation. Production of TIMP-1 and TIMP-2 by HSCs incubated with ethanol in the presence of 4-MP or with acetaldehyde was examined by ELISA and Western blot. As can be seen from Fig 7A and B, ethanol and acetaldehyde significantly increased TIMP-1 and TIMP-2 production. Zinc supplementation was a strong inhibitor of TIMP-1 production, as detected by more sensitive ELISA method, but in Western blot analysis inhibition was observed only when high $50 \mathrm{mM}$ concentration of ethanol was used. TIMP-2 production estimated using only Western blot analysis was $85 \%$ inhibited by zinc supplementation in HSCs treated with $50 \mathrm{mM}$ ethanol or $29 \%$ inhibited when induced by $175 \mu \mathrm{M}$ acetaldehyde (Fig 7a and B).

\subsection{Ethanol and acetaldehyde-induced NFkB activation is antagonized by zinc}

$\mathrm{NF \kappa B}$ is a ubiquitous transcription factor involved in the regulation of cytokine production and action and in the regulation of cell apoptosis. A number of studies have demonstrated that zinc influences the status of $\mathrm{NF} \kappa \mathrm{B}$ in various cell types [29]. Activation of $\mathrm{NF} \kappa \mathrm{B}$ is linked to phosphorylation and proteolytic degradation of $\mathrm{I} \kappa \mathrm{B} \alpha$ [30]. Therefore, we 
examined the influence of zinc supplementation on the levels of ethanol or acetaldehydeinduced NFkB in HSCs and also on its phosphorylation. Moreover, we examined the total level of IкB $\alpha$ and its phosphorylation. The experiment revealed that both $50 \mathrm{mM}$ ethanol and $175 \mu \mathrm{M}$ acetaldehyde increased total levels of $\mathrm{NF \kappa B}$ and significantly increased phosphorylation of its inhibitor $\mathrm{I} \kappa \mathrm{B} \alpha$, while decreasing the total level of the latter. Preincubation of HSCs with $30 \mu \mathrm{M} \mathrm{ZnCl}$ decreased the total level of ethanol- and acetaldehyde-induced $\mathrm{NF} \kappa \mathrm{B}$, increased the total level of its inhibitor I $\mathrm{KB} \alpha$, while significantly inhibiting the latter's phosphorylation (Fig. 8A and B).

\subsection{Zinc supplementation influences MAPK activation in HSCs}

Because cell growth and the expression of genes involved in cell growth and cytokine production are widely regulated through MAPK signal cascades, we assessed the effect of zinc supplementation on MAPK activity, including JNK and p38. Treatment of HSCs with both $50 \mathrm{mM}$ ethanol in the presence of 4-MP and with $175 \mu \mathrm{M}$ acetaldehyde significantly enhanced the phosphorylation of JNK and only slightly increased the phosphorylation of p38 MAPK (Fig 8A and B). Preincubation of HSCs with $30 \mu \mathrm{M} \mathrm{ZnCl} 2$ inhibited ethanol-induced phosphorylation of JNK and p38 MAPK by nearly $31 \%$ and $26 \%$, respectively, and acetaldehyde-induced phosphorylation of both JNK and p38 MAPK (Fig 8A and B) by nearly $50 \%$ and $30 \%$, respectively.

\subsection{Effect of zinc supplementation on the TGF- $\beta$-signaling pathway}

Because TGF- $\beta$ signal cascades through Smad 2 and Smad 3 strongly regulate the expression of type I collagen genes [9], we evaluated the effect of zinc supplementation on ethanol- and acetaldehyde-induced phosphorylation of Smad 3. Treatment with zinc 
suppressed ethanol- and acetaldehyde-induced phosphorylation of Smad 3 by nearly $75 \%$ (Fig 9A and B).

4.10. Zinc supplementation inhibits other than ethanol- or acetaldehyde-induced PKC signaling

Since it was detected that acetaldehyde-elicited overproduction of $\alpha$-SMA as a marker of HSC activation is, at least in part, connected with PKC activation, we examined whether preincubation of $\mathrm{HSCs}$ with $30 \mu \mathrm{M} \mathrm{ZnCl} 2$ might further inhibit $\alpha$-SMA production in the presence of calphostin, a well-known inhibitor of PKC. Calphostin significantly inhibited ethanol-and acetaldehyde-induced $\alpha$-SMA, but concomitant zinc supplementation inhibited a-SMA expression even more efficiently (Fig. 10A and B). It seems likely that zinc may inhibit other signaling pathways induced by ethanol or its metabolite than the PKC pathway.

\section{Discussion}

Our study explored the multiple effects of zinc supplementation on ethanol- or acetaldehyde-activated rat stellate cells (HSCs). Pretreatment of ethanol or acetaldehydeactivated $\mathrm{HSCs}$ with $30 \mu \mathrm{M} \mathrm{ZnCl} 2$ influenced several symptoms of $\mathrm{HSC}$ activation, caused a decrease in $\alpha$-SMA and procollagen type I production, and inhibited their motility, but had no effect on HSC proliferation activity. To assess the mechanisms by which zinc inhibited HSC activation, we examined its antioxidative properties. It is known that zinc supplementation attenuates ethanol-induced hepatic zinc depletion and suppresses ethanol-elevated C4502E1 activity, but increases the activity of $\mathrm{ADH}$ in the liver. In consequence zinc suppresses alcohol-induced oxidative stress [31]. In our experiments, zinc supplementation inhibited ethanol-induced (in the presence of the ADH inhibitor 4-methylpyrazole) or acetaldehydeinduced production of superoxide anion and hydrogen peroxide in HSCs. These results are in 
agreement with the results of other authors who detected that in HSCs zinc deficiency causes a reduction in intracellular glutathione levels and activation of the cells. Zinc supplementation reverses this process [21]. Of particular interest is the interaction between TGF- $\beta$ and ROS formation. In cultured HSCs, TGF- $\beta$ increases the production of hydrogen peroxide [32], which in turn induces the expression of $\alpha 1(\mathrm{I})$ procolagen mRNA [33,34]. The direct profibrogenic effect of hydrogen peroxide has also been observed in co-cultures of HSCs with HepG2 cells overexpressing CYP2E1 [35]. It should be stressed that in our study zinc supplementation inhibited both ROS generation and TGF- $\beta$ production.

In addition to its essential role in various immunological functions [36], zinc has a dual effect on the secretion of pro-inflammatory cytokines. It has been reported to trigger the release of these cytokines by monocytes [37], but suppression of cytokine production has also been found $[38,39]$. This is explained by a concentration-dependent process, in which low zinc doses potentiate cytokine production, while its high concentrations inhibit cytokine secretion [40]. In our experiment, we chose a rather low $30 \mu \mathrm{M}$ concentration of zinc, which did not exhibit any toxicity for HSCs in vitro, and which represented a maximal level of zinc attainable for humans after oral supplementation [41,42]. Zinc at this concentration significantly inhibited ethanol- and acetaldehyde-induced TGF- $\beta 1$ and TNF- $\alpha$ production in HSCs. In the experiments done by other authors in a mouse model of non-alcoholic steatosis, palaprezinc (a zinc-carnosine chelate compound) slightly reduced lipid peroxidation and suppressed HSC activation as well as mRNA expression of TGF- $\beta 1$ and TNF- $\alpha$ [43].

A number of reports show that zinc modulates several signaling pathways, among others $\mathrm{NF \kappa B}$ activation and the MAPK pathway [44]. It is also known that the NFkB and MAPK pathways, including p38 and JNK, participate in HSC activation $[45,46,47]$. Therefore, we examined the influence of $30 \mu \mathrm{M}$ zinc supplementation on NFKB, JNK and p38 MAPK activation and demonstrated an inhibitory effect of zinc on ethanol- or acetaldehyde-induced 
activation of the signaling pathways. It has been demonstrated that NFKB binding activity to $\kappa \mathrm{B}$ binding sites in several genes increases in liver macrophages and hepatocytes after $\mathrm{CCl}_{4}$ treatment of rats, and ongoing production of proinflammatory cytokines regulated by $\mathrm{NF \kappa B}$ is believed to play a major role in $\mathrm{CCl}_{4}$-induced liver fibrosis $[48,49,50]$. The key feature of liver fibrosis is the increase in collagen type I synthesis. It has been reported that Col1A2 promotor contains at least 2 putative NFkB binding sites [51]. Oxidative stress is the major factor inducing the phosphorylation of $\mathrm{I} \kappa \mathrm{B}$, which releases $\mathrm{NF} \kappa \mathrm{B}$, translocating it than the nucleus to activate the transcription of target genes [52]. Moreover, acetaldehyde itself is able to induce an early activation of $\mathrm{NF \kappa B}$ and AP-1 in HepG2 cells (via a PKC-dependent pathway) and in rat HSCs $[53,54,55]$. Additionally, acetaldehyde-elicited $\alpha 2(\mathrm{I})$ collagen gene expression in human HSCs is inhibited by calphostin, an inhibitor of PKC $[53,54]$. In our study, we also detected that, at least in part, overproduction of $\alpha$-SMA as a marker of HSC activation involved the PKC pathway, as calphostin inhibited ethanol- and acetaldehydeinduced $\alpha$-SMA expression.

A number of studies have implicated zinc in the control of NFKB and AP-1 activation $[56,57]$. However, the results of these studies regarding the outcome of zinc treatment with regard to the status of $\mathrm{NF \kappa B}$ and $\mathrm{AP}-1$ activities are inconsistent. Some reports suggest that zinc supplementation reduces the DNA binding activities of NFKB and AP-1 [56], while zinc chelation increases NFאB and AP-1 DNA binding [57]. Conversely, other studies demonstrate that the addition of zinc exerts an opposite effect on these transcription factors increasing the DNA binding activity of NFKB and AP-1 [58]. In yet another paper, zinc was shown to inhibit NFKB activity, but promote AP-1 activation in cancer cells [59]. Together these data indicated

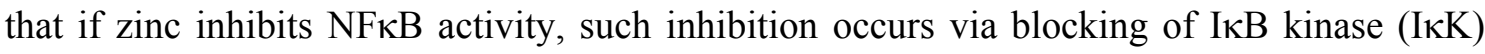
activity. Indeed, recent studies have demonstrated that thiol-reactive metal compounds inhibit 
$\mathrm{NF} \kappa \mathrm{B}$ activation by blocking IאK [60]. In our study, we also detected that zinc supplementation significantly inhibited phosphorylation of I $\mathrm{B}$ while increasing its total level.

The mechanisms by which ethanol and its metabolite regulate extracellular matrix (ECM) gene expression as markers of HSC activation have not been completely elucidated. Several centers have reported that the MAPK and PI-3K pathways are involved [47,61]. Anania et al. [47] noted that in rat HSCs, phospho-JNK was elevated following exposure to acetaldehyde. It seems likely that JNK is the principal mediator of acetaldehyde-induced $\alpha 1(\mathrm{I})$ collagen gene up-regulation in rat HSCs. These findings are consistent with those previously reported by Anania et al. [53]. Moreover, in rat pancreatic stellate cells (PSCs) ethanol and acetaldehyde at clinically relevant concentrations $(50 \mathrm{mM}$ and $200 \mu \mathrm{M}$, respectively) activated JNK and p38 MAPK. As ethanol- and acetaldehyde-induced activation of MAPK was blocked by the antioxidant $\mathrm{N}$-acetyl-cysteine, the role of oxidative stress in the signal transduction was suggested [62]. The JNK pathway may be involved in the migration of HSCs within the Disse space to the sites of tissue damage because the JNK inhibitor SP 600125 inhibits HSC migration induced by a TGF- $\beta$ signal $[47,61]$. The results of our study confirm the involvement of the p38 and JNK pathways in ethanol- and acetaldehyde-induced HSC activation. Moreover, JNK activation occurrs concomitantly with the enhanced HSC migratory activity. Zinc inhibited both JNK phosphorylation and HSC migration. It has also been detected that the inhibiting of either p38 MAPK or Smad signaling reduces $\alpha 1(\mathrm{I})$ collagen gene expression in untreated HSCs, and when both signaling pathways are simultaneously inhibited, $\alpha 1(\mathrm{I})$ collagen gene expression is essentially blocked [63]. These data indicate that not only MAPK pathways but also TGF- $\beta$-induced signaling is important in the activation of HSCs. In our study, zinc supplementation also significantly inhibited phosphorylation of Smad 3, suggesting that zinc can inhibit cellular processes upstream of 
both MAPK and TGF- $\beta$-induced signaling (probably oxidative stress), which, as described earlier, are responsible for the activation of MAPK and TGF- $\beta$ production in HSCs.

Our study has shown that HSCs can be a rich source of several MMPs, among others MMP-2 and MMP-13. Both ethanol, in the presence of 4-MP as an inhibitor of ADH, and acetaldehyde significantly modulated MMP activity. Moreover, our study demonstrated the expression of TIMP-1 and TIMP-2 proteins, especially after incubation of HSCs with ethanol and acetaldehyde. This is in accordance with the studies of Knittel et al. [64], who demonstrated that HSCs are a major source of MMP-2 and MMP-9 in the liver, and that MMP-2 is largely secreted in a latent form. Recent studies have also demonstrated that rat HSCs express mRNA for MMP-13. Both MMP-2 and MMP-9 are known to degrade basement membrane collagen while MMP-13 is known to degrade fibrillar collagen. Studies with HSCs have established that when activated, HSCs synthesize increased ECM proteins, particularly fibrillar collagen, but shut-down the expression of proteases such as MMP-13, which degrade fibrillar collagen $[65,66,67]$. Together these changes may facilitate the profibrogenic action of activated HSCs. Increased MMP-2 production at the early stages of cell activation may also be profibrogenic because it increases degradation of normal basement membrane collagen. Moreover, products of collagen degradation may exert a proliferative effect on HSCs [67] leading to an increase in the number of activated HSCs. Proliferation and invasiveness of HSCs could be prevented by specific MMP-2 inhibitors and antioxidants. On the other hand the later overexpression of MMP-2 may be important in the remodeling of martix during tissue repair processes [68,69]. The results of our study indicating enhanced MMP-2 activity after ethanol- or acetaldehyde-induced activation, suggest a profibrogenic action of ethanol and its metabolite. Zinc, which was detected to inhibit MMP-2 production seems to be antifibrotic in its action. However, the data concerning protective effect of zinc 
supplementation are contradictory because in some experiments zinc administration in already cirrhotic animals reduced lipid peroxidation but did not affect liver collagen content [70].

Regulation of ECM synthesis and its degradation by MMPs and their inhibitors (TIMPs) is a complex process. In general, TIMPs inhibit MMP activity by binding to active sites of MMPs. Our study has shown that TIMP-1 and TIMP-2 secretion was induced in HSCs by ethanol and acetaldehyde. This finding is similar to previously reported results demonstrating a significant TIMP expression after HSC activation [71]. In our study, zinc supplementation significantly inhibited the production of both TIMP-1 and TIMP-2. These results seem to confirm data from in vivo experiments with oral zinc supplementation, in which an increased level of zinc in patients down-regulated the level of TIMP-1 in their sera [23]. As TIMP-1 was described [72] to have an antiapoptotic effect on activated HSCs, such a decrease in its production can be beneficial for liver fibrosis resolution.

Summing up, the results of our experiments revealed that zinc can exert an antifibrotic activity by silencing ethanol- or acetaldehyde activated HSCs. The possible mechanisms of antifibrotic effect of $\mathrm{ZnCl}_{2}$ are presented on Fig. 11. Zinc supplementation inhibited ethanoland acetaldehyde-induced ROS production, which seems to be a key mechanism in its inhibitory action on $\alpha$-SMA and procollagen I expression. Zinc was also shown to inhibit TGF- $\beta$ and TNF- $\alpha$ production, probably by its inhibitory action on the NF- $\kappa$ B pathway. Moreover, zinc also attenuated HSC activation via down-regulation of p38 MAPK, JNK and TGF- $\beta$ signaling activation induced by ethanol or acetaldehyde. Inhibition by zinc of MMP-2, TIMP-1 and TIMP-2 production by HSCs seems to be an additional mechanism of its antifibrotic activity. 


\section{Acknowledgments}

This work was supported by grant No 2 P05A 16929 from the Ministry of Science and Higher Education.

We gratefully acknowledge Dr Marcos Rojkind for the generous donation of the rat HSC line CFSC-2G.

\section{References}

[1] Bataller R, Brenner DA. Liver fibrosis. J Clin Invest 2005;115:209-218.

[2] Senoo H. Structure and function of hepatic stellate cells. Med Electron Microsc 2004;37: $3-15$.

[3] Siegmund SV, Dooley S, Brenner DA. Molecular mechanisms of alcohol-induced hepatic fibrosis. Dig Dis 2005;23:264-274.

[4] Brenzel A, Gressner AM. Characterization of insulin-like growth factor (IGF)-I-receptor binding sites during in vitro transformation of rat hepatic stellate cells to myofibroblasts. Eur J Clin Chem Clin Biochem 1996;34:401-409.

[5] Wong L, Yamasaki G, Johnson RJ, Friedman SL. Induction of platelet-derived growth factor receptor in rat hepatic lipocytes during cellular activation in vivo and in culture. J Clin Invest 1994;94:1563-1569.

[6] Friedman SL, Wong L. Modulation of transforming growth factor $\beta$ receptors of rat lipocytes during the hepatic wound healing response. Enhanced binding and reduced gene expression accompany cellular activation in culture and in vivo. J Biol Chem 1994:269: 10551-10558.

[7] Yata Y, Gotwals P, Koteliansky V, Rockey DC. Dose-dependent inhibition of hepatic fibrosis in mice by a TGF- $\beta$ soluble receptor: implication for antifibrotic therapy. Hepatology $2002 ; 35: 1022-1030$. 
[8] Liu C, Gaca MDA, Swenson ES, Vellucci VF, Reiss M, Wells RG. Smads 2 and 3 are differentially activated by transforming growth factor $\beta$ (TGF- $\beta$ ) in quiescent and activated hepatic stellate cells. J Biol Chem 2003;278: 11721-11728.

[9] Uemura M, Swenson ES, Gaca MDA, Giordano FJ, Reiss M, Wells RG. Smad2 and Smad3 play different roles in rat hepatic stellate cell function and $\alpha$-smooth muscle actin organization. Mol Biol Cell 2005;16:4214-4224.

[10] Svegliani-Baroni G, Ridolfi F, Di Sario A, Saccomanno S, Bendia E, Benedetti A, Greenwel P. Intracellular signalling pathways involved in acetaldehyde-induced collagen and fibronectin gene expression in human stellate cells. Hepatology 2001;33: 1130-1140.

[11] Novistskiy G, Potter JJ, Rennie-Tankersley L, Mezey E. Identification of novel NF-kB binding site with regulation of the murine $\alpha_{2}(\mathrm{I})$ collagen promoter. J Biol Chem 2004;279: $15639-15644$.

[12] Novitskiy G, Ravi R, Potter JJ, Rennie-Tankersley L, Wang L, Mezey E. Effect of acetaldehyde and TNF $\alpha$ on the inhibitory kappa B- $\alpha$ protein and nuclear factor kappa B activation in hepatic stellate cells. Alcohol Alcoholism 2005;40:96-101.

[13] Greenwel P, Domingez-Rosales JA, Mavi G, Rivas-Estilla AM, Rojkind M. Hydrogen peroxide: a link between acetaldehyde-elicited alphal (I) collagen gene up-regulation and oxidative stress in mouse hepatic stellate cells. Hepatology 2000;31:109-116.

[14] Svegiati-Baroni G, Inagaki Y, Rincon-Sanchez AR, Else C, Saccomanno S, Benedetti A, Ramirez F, Rojkind M. Early response of $\alpha 2$ (I) collagen to acetaldehyde in human hepatic stellate cells is TGF- $\beta$ independent. Hepatology 2005;42:343-352.

[15] Nieto N, Geenwel P, Friedman SL, Zhang F, Dannenberg AJ, Cederbaum AI. Ethanol and arachidonic acid increase $\alpha 2(\mathrm{I})$ collagen expression in rat hepatic stellate cells overexpressing cytochrome $\mathrm{P} 450$ 2E1. Role of $\mathrm{H}_{2} \mathrm{O}_{2}$ and cyclooxygenase-2. J Biol Chem 2005;275:20136-20145. 
[16] McCarrol JA, Phillips PA, Park S, Doherty E, Pirola RC, Wilson JS, Apte MV. Pancreatic stellate cell activation by ethanol and acetaldehyde: is it mediated by the mitogenactivated protein kinase signalling pathway? Pancreas 2003;27:150-160.

[17] Nishitani Y, Matsumoto H. Ethanol rapidly causes activation of JNK associated with ER stress under inhibition of ADH. FEBS Lett 2006;580:9-14.

[18] Zhou X, Jamil A, Nash A, Chan J, Trim N, Iredale JP, Benyon RC. Impaired proteolysis of collagen I inhibits proliferation of hepatic stellate cells. Implications for regulation of liver fibrosis. J Biol Chem 2006;281:39757-39765.

[19] Han YP. Matrix metalloproteinases, the pros and cons, in liver fibrosis. J Gastroenterol Hepatol 2006;21:S88-S91.

[20] Bode JC, Hanish P, Henning H, Koenig W, Richter FW, Bode C. Hepatic zinc content in patients with various stages of alcoholic liver disease and in patients with chronic active and chronic persistent hepatitis. Hepatology 1998;8:1605-1609.

[21] Kojima-Yuasa A, Umeda K, Ohkita T, Opare Kenedy D, Nishigushi S, Matsui-Yuasa I. Role of reactive oxygen species in zinc deficency-induced hepatic stellate cell activation. Free Radic Biol Med 2005;39:631-640.

[22] Kojima-Yuasa A, Ohkita T, Yukami K, Ichikawa H, Takami N, Nakatani T, et al. Involvement of intracellular glutathione in zinc deficiency-induced activation of hepatic stellate cells. Chem. Biol. Interact. 2003;146: 89-99.

[23] Takahashi M, Saito H, Higashimoto M, Hibi T. Possible inhibitory effect of zinc supplementation on hepatic fibrosis through downregulation of TIMP-1. A pilot study. Hepatol Res 2007;37:405-409.

[24] Yoshiji H, Kuriyama S, Yoshiji J, Ikenaka Y, Noguchi R, Nakatani T, et al. Tissue inhibitor of metallopreoteinases-1 attenuates spontaneous liver fibrosis resolution in the transgenic mouse. Hepatology 2002;36:850-860. 
[25] Mayo LA, Curnutte JT. Kinetic microplate assay for superoxide production by neutrophils and other phagocytic cells. Meth Enzymol 1990;186:571-575.

[26] Pick E. Microassays for superoxide and hydrogen peroxide production and nitroblue tetrazolium reduction using an enzyme immunoassay microplate reader. Meth Enzymol 1986; 132: 414-419.

[27] Yamada T, Imaoka S, Kawada N, Seki S, Kuroki T, Kobayashi K, et al. Expression of cytochrome P450 isoforms in rat hepatic stellate cells. Life Sci 1997;61:171-179.

[28] Yamauchi M, Potter JJ, Mezey E. Characteristics of alcohol dehydrogenase in fat-storing (Ito) cells of rat liver. Gastroenterology 1998;94:163-169.

[29] Prasad AS, Bao B, Beck FWJ, Sarkar FH. Zinc activates NF kappa B in HUT-78 cells. J Lab Clin Med 2001;138:250-256.

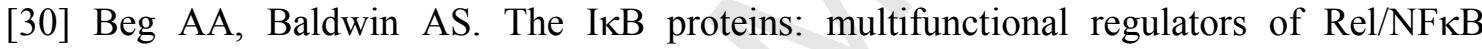
transcription factors. Genes Dev 1993;7:2064-2070.

[31] Kang YJ, Zhou Z. Zinc prevention and treatment of alcoholic liver disease. Mol Aspects Med 2005;26:391-404.

[32] De Bleser P, Xu G, Rombouts K, Rogiers V, Geerts A. Glutathione levels discriminate between oxidative stress and transforming factor $\beta$ signalling in activated rat hepatic stellate cells. J Biol Chem 1999;274:33881-33887.

[33] Garcia-Trevijano ER, Iraburu MJ, Fontana L, Dominguez-Rosales JA, Auster A, Covarrubias-Pinedo, et al. Transforming growth factor $\beta 1$ induces the expression of $\alpha 1(\mathrm{I})$ procollagen mRNA by a hydrogen peroxide-C/EBP $\beta$-dependent mechanism in rat hepatic stellate cells. Hepatology 1999;29:960-970.

[34] Geenwel P, Domingez-Rosales JA, Mavi G, Rivasestilla AM, Rojkind M. Hydrogen peroxide: a link between acetaldehyde-elicited alpha1(I) collagen gene up-regulation and oxidative stress in mouse hepatic stellate cells. Hepatology 2000;31:109-116. 
[35] Nieto N, Friedman SL, Cederbaum A. Stimulation and proliferation of primary rat hepatic stellate cells by cytochrome P450 2E1-derived reactive oxygen species. Hepatology 2000;35:62-73.

[36] Rink L, Gabriel P. Extracellular and immunological actions of zinc. Biometals. 2001;14: $367-383$

[37] Driessen C, Hirv K, Rink L, Kirchner H. Induction of cytokines by zinc ions in human peripheral blood mononuclear cells and separated monocytes. Lymphokine Cytokine Res. $1994 ; 13: 15-20$.

[38] Bao B, Prasad AS, Beck FW, Godmere M. Zinc modulates mRNA levels of cytokines. Am. J. Physiol. 2003;285:E1095-E1102.

[39] Zhou Z, Wang L, Song Z, Saari JT, McClain CJ, Kang YJ. Abrogation of nuclear factor $\kappa \mathrm{B}$ activation is involved in zinc inhibition of lipopolysaccharide-induced tumor necrosis factor $\alpha$ production and liver injury. Am J Pathol 2004;164:1547-1556.

[40] Driessen C, Hirv K, Kirchner H, Rink L. Divergent effects of zinc on different bacterial pathogenic agents. J Infect Dis 1995;171:486-489.

[41] Sullivan VK, Cousins RJ. Competitive reverse transcriptase-polymerase chain reaction shows that dietary zinc supplementation in humans increases monocyte metallothionein mRNA levels. J Nutr 1997;127:694-698.

[42] Von Bulow V, Dubben S, Engelhardt G, Hebel S, Plumakers B, Heine H, et al. Zincdependent suppression of TNF $\alpha$ production is mediated by protein kinase A-induced

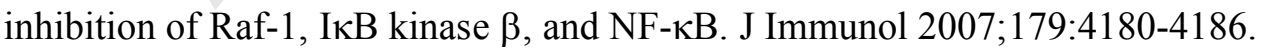

[43] Sugino H, Kumagai N, Watanabe S, Toda K, Takeuchi O, Tsunematsu S, et al. Polaprezinc attenuates liver fibrosis in a mouse model of non-alcoholic steatohepatitis. $\mathrm{J}$ Gastroenterol Hepatol 2008;12:1909-1916. 
[44] Wu W, Silbajoris RA, Whang YE, Graves LM, Bromberg PA, Samet JM. p38 and EGF receptor kinase-mediated activation of the phosphatidylinositol 3-kinase/Akt pathway is required for $\mathrm{Zn}^{2+}$ induced cyclooxygenase-2 expression. Am J Physiol Lung Cell Mol Physiol 2005;289:L883-889.

[45] Rippe RA, Schrum LW, Stefanovic B, Solis-Herruzo JA, Brenner DA. NF-kappa B inhibits expression of alpha1 (I) collagen gene. DNA Cell Biol 1999;18:751-761.

[46] Valera-Rey M, Montiel-Duarte C, Oses-Preito JA, Lopez-Zabulza MJ, Jaffrezou JP, Rojkind M. et al. p38 MAPK mediates the regulation of $\alpha 1(\mathrm{I})$ procolagen mRNA levels by TNF- $\alpha$ and TGF- $\beta$ in a cell line of rat hepatic stellate cells. FEBS Lett 2002;528:133-138.

[47] Anania FA, Womack L, Jiang M, Saxena NK. Aldehydes potentiate $\alpha_{2}(\mathrm{I})$ collagen gene activity by JNK in hepatic stellate cells. Free Rad Biol Med 2001;30:846-857.

[48] Orfila C, Lepert JC, Alric L, Carrera G, Beraud M, Pipy B. Immunohistochemical distribution of activated nuclear factor kappaB and peroxisome proliferator-activated receptors in carbon tetrachloride-induced chronic liver injury in rats. Histochem Cell Biol 2005;123:585-593.

[49] Son G, Iimuro Y, Seki E, Hirano T, Kaneda Y, Fujimoto J. Selective inactivation of NF$\kappa \mathrm{B}$ decoy suppresses $\mathrm{CCl}_{4}$-induced liver injury and fibrosis. Am J Physiol Gastrointest Liver Physiol 2007;293:G631-G639.

[50] Jaruga B, Hong F, Kim WH, Sun R, Fan S, Gao B. Chronic alcohol consumption accelerates liver injury in $\mathrm{T}$ cell-mediated hepatitis: alcohol disregulation of $\mathrm{NF}-\kappa \mathrm{B}$ and STAT3 signalling pathways. Am J Physiol Gastrointest Liver Physiol 2006;287:G471-G479. [51] Buttner C, Skupin A, Rieber EP. Transcriptional activation of the type I collagen genes COL1A1 and COL1A2 in fibroblasts by interleukin-4: analysis of the functional collagen promoter sequences. J Cell Physiol 2004;198:248-258. 
[52] Bowie A, O'Neill LA. Oxidative stress and nuclear factor-kappaB activation: a reassessment of the evidence in the light of recent discoveries. Biochem Pharmacol 2000;59: $13-23$.

[53] Anania FA, Womack L, Potter JJ, Mezey E. Acetaldehyde enhances murine alpha2(I) collagen promoter activity by $\mathrm{Ca}^{2+}$-independent protein kinase $\mathrm{C}$ activation in cultured rat hepatic stellate cells. Alcohol Clin Exp Res 1999;23:279-284.

[54] Casini A, Galli G, Salzano R, Rotella CM, Surrenti C. Acetaldehyde induces c-fos and cjun proto-oncogenes in fat storing cell cultures through protein kinase $\mathrm{C}$ activation. Alcohol Alcohol 1994;29:303-314.

[55] Nieto N. Ethanol and fish oil induce NF- $\mathrm{B}$ transactivation of the collagen $\alpha 2(\mathrm{I})$ promoter through lipid peroxidation-driven activation of PKC-PI3K-Akt pathway. Hepatology 2007;45:1433-1445.

[56] Connell P, Young VM, Toborek M, Cohen DA, Barve S, McClain CJ, et al. Zinc attenuates tumor necrosis factor-mediated activation of transcription factors in endothelial cells. J Am Coll Nutr 1997;16:411-417.

[57] Meerarani P, Reiterer G, Toborek M, Hennig B. Zinc modulates PRARgamma signalling and activation of porcine endothelial cells. J Nutr 2003;133:3058-3064.

[58] Kim CH, Kim JH, Lee J, Ahn YS. Zinc-induced NF-kappaB inhibition can be modulated by changes in the intracellular metallothionein level. Toxicol Appl Pharmacol 2003;190:189196.

[59] Uzzo RG, Crispen PL, Golovine K, Makhov P, Horwitz EM, Kolenko VM. Diverse effects of zinc on NF- $\mathrm{kB}$ and $\mathrm{AP}-1$ transcription factors: implication for prostate cancer progression. Carcinogenesis 2006;27:1980-1990.

[60] Jeon KI, Jeong JY, Jue DM. Thiol-reactive metal compounds inhibit NF-kappaB activation by blocking I kappaB kinases. J Immunol 2000;164:5981-5989. 
[61] Yoshida K, Matsuzaki K, Mori S, Tahashi Y, Yamagata H, Furukawa F, et al. Transforming growth factor- $\beta$ and platelet-derived growth factor signal via c-Jun N-terminal kinase-dependent Smad2/3 phosphorylation in rat hepatic stellate cells after acute liver injury. Am J Pathol 2005;166:1029-1039.

[62] Masamune A, Kikuta K, Satoh M, Satoh A, Shimosegawa T. Alcohol activates activator protein-1 and mitogen-activated protein kinases in rat pancreatic stellate cells. J Pharmacol Exp Ther 2002;302:36-42.

[63] Tsukada S, Westwick JK, Ikejima K, Sato N, Rippe RA. SMAD and p38 MAPK signalling pathways independently regulate $\alpha 1(\mathrm{I})$ collagen gene expression in unstimulated and transforming growth factor- $\beta$-stimulated hepatic stellate cells. J Biol Chem 2005;280:10055-10064.

[64] Knittel T, Mehde M, Kobold D, Saile B, Dinter C, Ramadori G. Expression patterns of matrix metalloproteinases and their inhibitors in parenchymal and non-parenchymal cells of rat liver: regulation by TNF-alpha and TGF-beta1. J Hepatol 1999;30:48-60.

[65] Iredale JP, Goddard S, Murhy G, Beyon RC, Arthur MJ. Tissue inhibitor of metalloproteinase-I and interstitial collagenase expression in autoimmune chronic active hepatitis and activated human lipocytes. Clin Sci (Lond) 1995;89:75-81.

[66] Beyon RC, Iredale JP, Goddard S, Winwood PJ, Arthur MJ. Expression of tissue inhibitor of metalloproteinases 1 and 2 is increased in fibrotic human liver. Gastroenterology $1996 ; 110: 821-831$.

[67] Beyon RC, Hovell CJ, Da Gaca M, Jones EH, Iredale JP, Arthur MJ. Progelatinase A is produced and activated in rat hepatic stellate cells and promotes their proliferation. Hepatology 1999;30:977-986.

[68] Urtasun R, Conde de la Rosa L, Nieto N. Oxidative and nitrosative stress and fibrogenic response. Clin Liver Dis 2008;12:769-790. 
[69] Han Y-P. Matrix metalloproteinases, the pros and cons, in liver fibrosis. J Gastroenterol Hepatol 2006;21:S88-S91.

[70] Stamoulis J, Kouraklis G, Theocharis S. Zinc and the liver: an active interaction. Dig Dis Sci 2007;52:1595-1612.

[71] Iredale JP, Murphy G, Hembry RM, Friedman SL, Arthur MJ. Human hepatic lipocytes synthesize tissue inhibitor of metalloproteinase-1. Implication for regulation of matrix degradation in liver. J Clin Invest 1992;90:282-287.

[72] Yoshiji H, Kuriyama S, Yoshii J, Ikenaka Y, Noguchi R, Nakatani T, et al. Tissue inhibitor of metalloproteinase-1 attenuates spontaneous liver fibrosis resolution in the transgenic mice. Hepatology 2002;36:850-860.

Figure legends

Fig. 1

The influence of zinc supplementation on ethanol- (A) and acetaldehyde- (B) induced toxicity in CFSC-2G cells.

CFSC-2G cells were preincubated with $30 \mu \mathrm{M} \mathrm{ZnCl} 2$ for $24 \mathrm{~h}$. Thereafter, ethanol or acetaldehyde at indicated concentrations were added. After $24 \mathrm{~h}$ of incubation, the toxicity was determined by MTT method. Values are means \pm SD of results from five experiments.

* Statistically significant at $\mathrm{p} \leq 0.05$ in comparison to cells incubated with ethanol or acetaldehyde alone (Wilcoxon test).

Fig. 2

CFSC-2G cells metabolize ethanol via the ADH and the P4502E1 pathways. (A) The cells were incubated with $2 \mathrm{mM}$ DAS or $2 \mathrm{mM} 4-\mathrm{MP}$ or with a mixture of the inhibitors. After $24 \mathrm{~h}$ of incubation, oxygen burst was induced by $50 \mathrm{mM}$ ethanol. Superoxide anion production was 
measured by cytochrome c reduction assay. Preincubation of CFSC-2G cells for $24 \mathrm{~h}$ with 30 $\mu \mathrm{M} \mathrm{ZnCl} 2$ inhibits ethanol and acetaldehyde induced superoxide anion (B) or hydrogen peroxide (C) production. Results are expressed as mean \pm SD of four independent experiments. *Significantly different from respective control (cells incubated without inhibitors) (A), cells not treated or treated only with zinc (B,C), $\mathrm{p} \leq 0.05$. \#Statistically significant at $\mathrm{p} \leq 0.05$ in comparison to cells treated with ethanol or acetaldehyde alone. Zinc significantly changed the ethanol/acetaldehyde effect, $\mathrm{p} \leq 0.001$ (two-way ANOVA).

Fig. 3

Preincubation of CFSC-2G cells for $24 \mathrm{~h}$ with $30 \mu \mathrm{M} \mathrm{ZnCl}$ induces quiescence of cells activated by $24 \mathrm{~h}$ incubation with ethanol in the presence of 4-MP (A) or with acetaldehyde (B). The markers of HSCs activation such as $\alpha$-SMA and procollagen I were measured by Western blot. $\beta$-actin expression served as loading control. On the right, the arrows indicate the position of the molecular weight markers used in the experiments. Representative blots are shown. Experiments were done in triplicates and the bar represents the mean \pm SD. *Significantly different from respective control (cells incubated with 4-MP) (A), cells not treated or treated only with zinc $(A, B) ;{ }^{*} p \leq 0.05, * * p \leq 0,01$. \#Statistically significant at $p \leq 0.05$ in comparison to cells treated with ethanol or acetaldehyde alone. Zinc significantly changed the ethanol/acetaldehyde effect, $p \leq 0,001$ (two-way ANOVA).

Fig. 4

Preincubation of CFSC-2G cells with $30 \mu \mathrm{M} \mathrm{ZnCl} 2$ inhibits cell migration. (A) A wound healing assay was performed on CFSC-2G cells grown to a confluent cell layer in which a wound was scraped to remove a linear area of cells, and cultures were treated with $30 \mu \mathrm{M}$ $\mathrm{ZnCl}_{2}$ for $24 \mathrm{~h}$. Then ethanol or acetaldehyde at indicated concentrations were added and the 
cells were allowed $24 \mathrm{~h}$ to migrate. Representative images of different conditions are shown. A chemotaxis assay (B) was performed in serum starved cells placed in Boyden chambers, in which the bottom chamber contained $30 \mu \mathrm{M} \mathrm{ZnCl} 2$ enriched medium. After $24 \mathrm{~h}$ of incubation, $175 \mu \mathrm{M}$ acetaldehyde was added into the bottom chamber. The number of cells migrating through membranes coated with Matrigel was counted under a microscope and shown as mean $\pm \mathrm{SD}$ of three independent experiments. ${ }^{*}$ Statistically significant at $\mathrm{p} \leq 0.05$ in comparison to respective control (cells not treated or treated only with zinc). \#Statistically significant at $\mathrm{p} \leq 0.05$ in comparison to cells treated with ethanol or acetaldehyde alone (Wilcoxon test).

Fig. 5

Preincubation of CFSC-2G cells with $30 \mu \mathrm{M} \mathrm{ZnCl} 2$ inhibits ethanol (A,B) or acetaldehyde $(\mathrm{C}, \mathrm{D})$ induced production of TGF- $\beta$ and TNF- $\alpha$. The cells were preincubated with $30 \mu \mathrm{M}$ $\mathrm{ZnCl}_{2}$ for $24 \mathrm{~h}$ and thereafter induced to produce cytokines by addition of ethanol or acetaldehyde at indicated concentrations. The level of cytokines was measured by ELISA and shown as mean \pm SD of three independent experiments. *Significantly different from respective control (cells not treated or treated only with zinc), $\mathrm{p} \leq 0.01$. \#Statistically significant at $\mathrm{p} \leq 0.05$ in comparison to cells treated with ethanol or acetaldehyde alone. Zinc significantly changed the ethanol/acetaldehyde effect, $\mathrm{p} \leq 0.01$ (two-way ANOVA).

Fig. 6

Preincubation of CFSC-2G cells with $30 \mu \mathrm{M} \mathrm{ZnCl} 2$ decreases production of MMP-2 induced by ethanol (A) or acetaldehyde (B). The MMP-2 level was estimated by ELISA. *Significantly different from respective control (cells not treated or treated only with zinc), $\mathrm{p} \leq 0.01$. \#Statistically significant at $\mathrm{p} \leq 0.05$ in comparison to cells treated with ethanol or 
acetaldehyde alone. Zinc significantly changed the ethanol/acetaldehyde effect, $\mathrm{p} \leq 0.01$ (twoway ANOVA).

Fig. 7

The effect of preincubation of CFSC-2G cells with $30 \mu \mathrm{M} \mathrm{ZnCl} 2$ on parameters related to extracellular matrix remodeling induced by ethanol (A) or acetaldehyde (B). Western blot analysis for TIMP-1, TIMP-2 and MMP-13 was performed on cell lysates derived from cells preincubated for $24 \mathrm{~h}$ with $30 \mu \mathrm{M} \mathrm{ZnCl}_{2}$ and thereafter for $24 \mathrm{~h}$ with the indicated ethanol or acetaldehyde concentrations. The upper panel shows representative blots, the middle - a densitometry analysis of bands, and the lower - TIMP-1 ELISA assay. *Significantly different from respective control (cells not treated or treated only with zinc), $\mathrm{p} \leq 0.01$. \#Statistically significant at $\mathrm{p} \leq 0.05$ in comparison to cells treated with ethanol or acetaldehyde alone. Zinc significantly changed the ethanol/acetaldehyde effect, $\mathrm{p} \leq 0.01$ (two-way ANOVA).

Fig. 8

The effect of preincubation of CFSC-2G cells with $30 \mu \mathrm{M} \mathrm{ZnCl} 2$ on phosphorylation of $\mathrm{NF} \kappa \mathrm{B}, \mathrm{I} \kappa \mathrm{B}, \mathrm{JNK}$ and p38 MAPK. The cells were preincubated with $30 \mu \mathrm{M} \mathrm{ZnCl} 2$ for $24 \mathrm{~h}$ and thereafter not exposed or exposed to $50 \mathrm{mM}$ ethanol (A) or $175 \mu \mathrm{M}$ acetaldehyde (B) for 20 min. The relative densitometry readings (mean \pm SD) from three independent experiments are shown. The upper panel shows representative blots of total and phosphorylated forms of $\mathrm{NF} \kappa \mathrm{B}, \mathrm{I} \kappa \mathrm{B}, \mathrm{JNK}$ and p38 MAPK. *Significantly different from respective control (cells incubated with 4-MP (A), cells not treated or treated only with zinc $(\mathrm{A}, \mathrm{B}) ;{ }^{*} \mathrm{p} \leq 0.05$, $* * \mathrm{p} \leq 0.001$. \#Statistically significant at $\mathrm{p} \leq 0.05$ in comparison to cells treated with ethanol or acetaldehyde alone (Wilcoxon test). 
Fig. 9

The effect of preincubation of CFSC-2G cells with $30 \mu \mathrm{M} \mathrm{ZnCl}_{2}$ on phosphorylation of Smad 3. The cells were preincubated with $30 \mu \mathrm{M} \mathrm{ZnCl} 2$ for $24 \mathrm{~h}$ and then induced by $50 \mathrm{mM}$ ethanol (A) or $175 \mu \mathrm{M}$ acetaldehyde (B) for $24 \mathrm{~h}$. The amounts of phosphorylated and total Smad 3 (used as loading control) were measured by Western blotting. The upper panel shows representative blots. Each figure is representative of three independent experiments. Bond intensities were measured, and the ratio of phosphorylated Smad 3 in the absence of $\mathrm{ZnCl}_{2}$ and ethanol or acetaldehyde was used as a control (100\%). The values shown are the mean \pm SD of triplicate determination. *Significantly different from respective control (cells incubated with 4-MP (A), cells not treated or treated only with zinc $(A, B),{ }^{*} \mathrm{p} \leq 0.05$. \#Statistically significant at $\mathrm{p} \leq 0.05$ in comparison to cells treated with ethanol or acetaldehyde alone (Wilcoxon test).

Fig. 10

Zinc supplementation inhibits pathways other than the PKC pathway. CFSC-2G cells were preincubated with $30 \mu \mathrm{M} \mathrm{ZnCl} 2$ for $24 \mathrm{~h}$ in the presence of 4-MP and with the addition or in the absence of $1 \mu \mathrm{M}$ calphostin $\mathrm{C}$ (a PKC inhibitor), and then ethanol at different concentrations (A) or $175 \mu \mathrm{M}$ acetaldehyde (B) were added. The cells were incubated for another $24 \mathrm{~h}$ and harvested for Western blot analysis. $\alpha$-SMA as a marker of cell activation was estimated. The upper panel shows representative blots. The lower panel shows a densitometry analysis of bands. *Significantly different from respective control (cells not treated or treated with 4-MP, calphostin $\mathrm{C}$ or zinc alone), $\mathrm{p} \leq 0.01$. \#Statistically significant at $\mathrm{p} \leq 0.05$ in comparison to cells treated with ethanol or acetaldehyde alone. Zinc significantly changed the ethanol/acetaldehyde effect, $\mathrm{p} \leq 0.01$ (two-way ANOVA). 


\section{Fig. 11}

Possible mechanisms of $\mathrm{ZnCl}_{2}$ antifibrotic effects in hepatic stellate cells treated with ethanol or acetaldehyde. Zinc attenuates oxidative stress, phosphorylation of kinases p38 and JNK as well as Smad 3. In the effect, it down-regulates collagen type I gene expression. 


\section{Table 1.}

The influence of preincubation of CFSC-2G cells with $30 \mu \mathrm{M}$ zinc for $24 \mathrm{~h}$ on apoptosis induced by ethanol or acetaldehyde. Caspase 3 activity was determined by Colorimetric Assay Kit.

\begin{tabular}{|l|c|c|}
\hline \multirow{2}{*}{} & \multicolumn{2}{|c|}{ Caspase 3 (fold increase) } \\
\cline { 2 - 3 } & - & Zn $30 \mu \mathrm{M}$ \\
\hline Ethanol $100 \mathrm{mM}$ & $1,96 \pm 0,3^{*}$ & $1,21 \pm 0,2 \#$ \\
\hline Acetaldehyde $175 \mu \mathrm{M}$ & $1,3 \pm 0,24$ & $1,14 \pm 0,17$ \\
\hline- & 1 & $1,1 \pm 0,15$ \\
\hline
\end{tabular}

* statistically significant in comparison to control (cells incubated without inductors), $\mathrm{p} \leq 0.05$ \# statistically significant in comparison to cells not treated with $\mathrm{ZnCl}_{2}, \mathrm{p} \leq 0.05$ (two-way ANOVA) 
Fig. 1.

$\mathbf{A}$

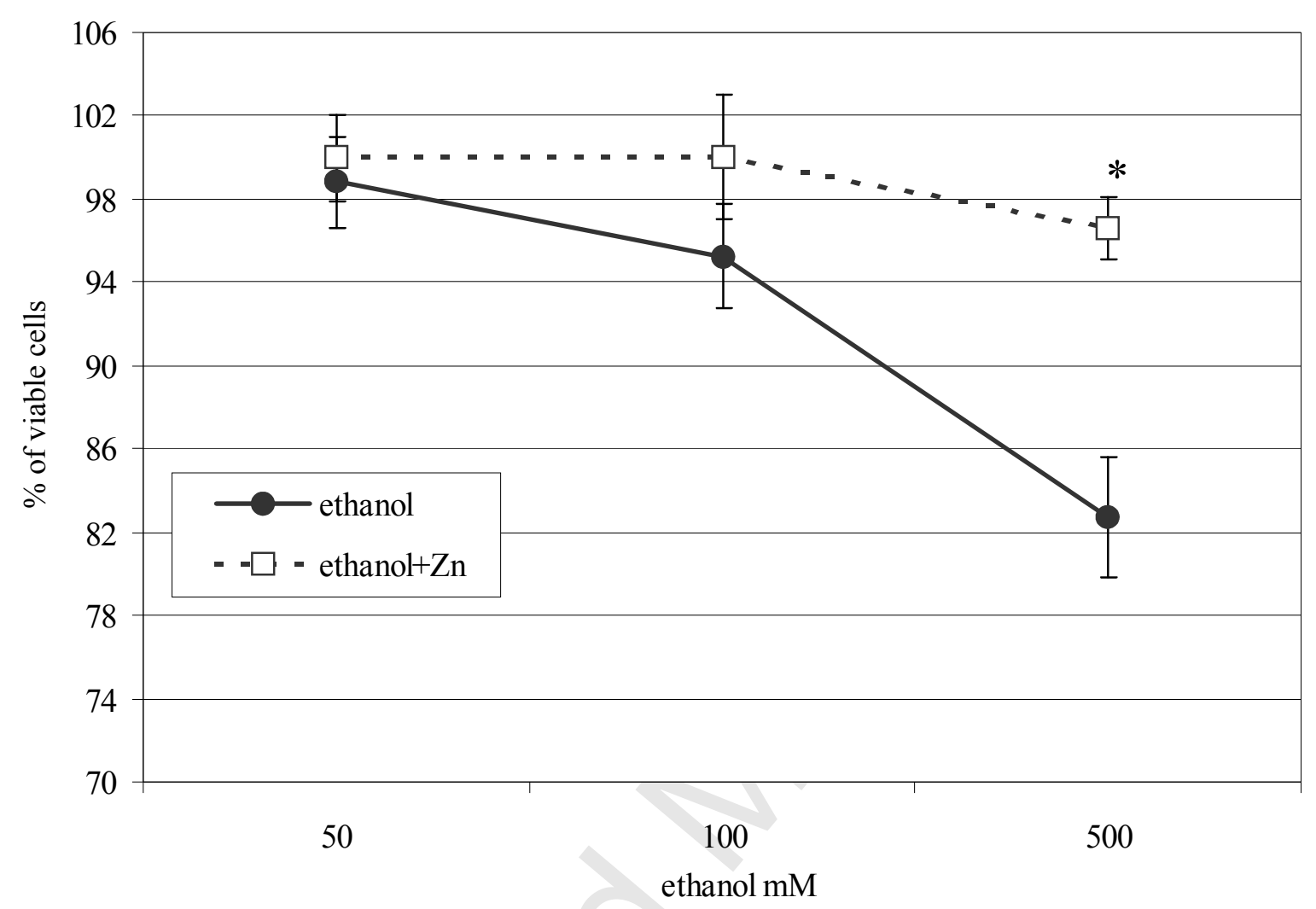

B

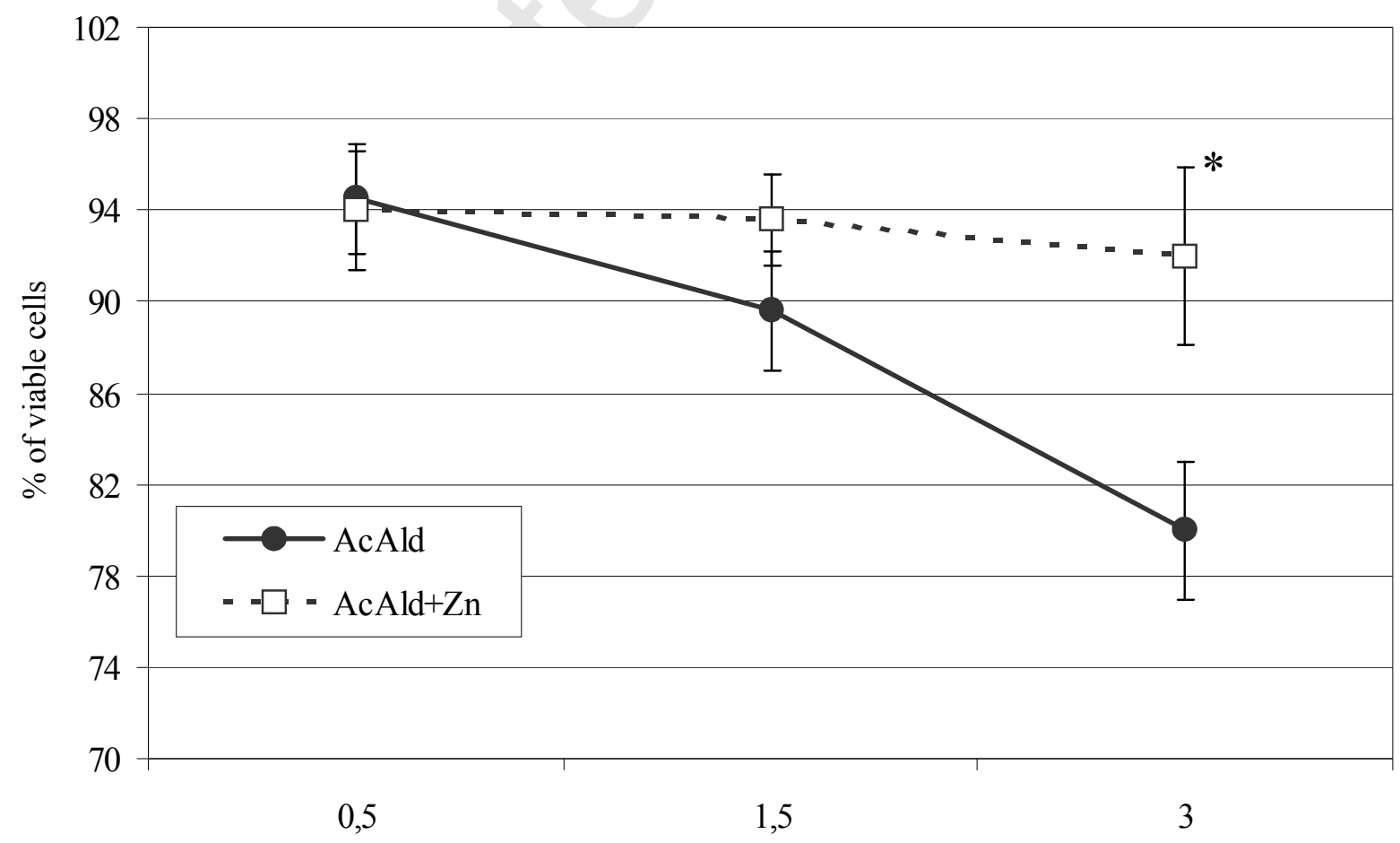

acetaldehyde $\mathrm{mM}$ 
Fig. 2.

A

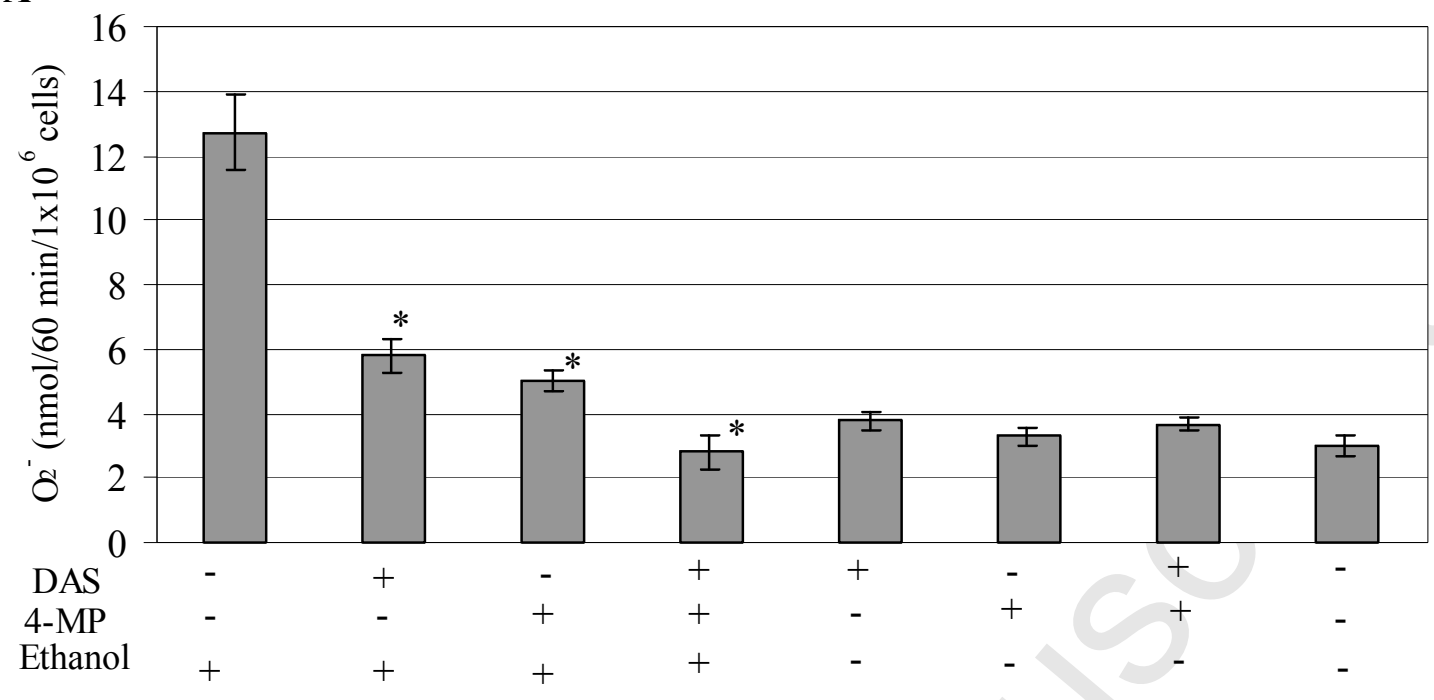

B

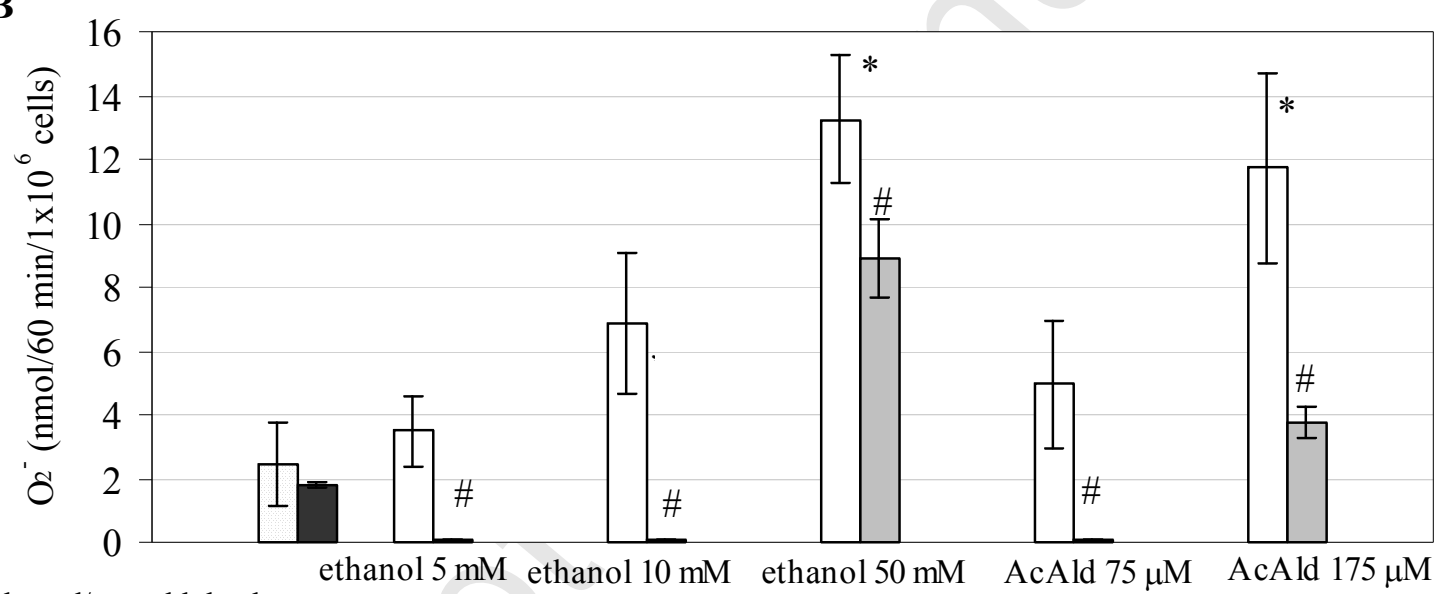

ethanol/acetaldehyde (AcAld) zinc $30 \mu \mathrm{M}$

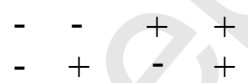

$+\quad+\quad+$

$\begin{array}{llll}+ & + & + & + \\ - & + & - & +\end{array}$

C

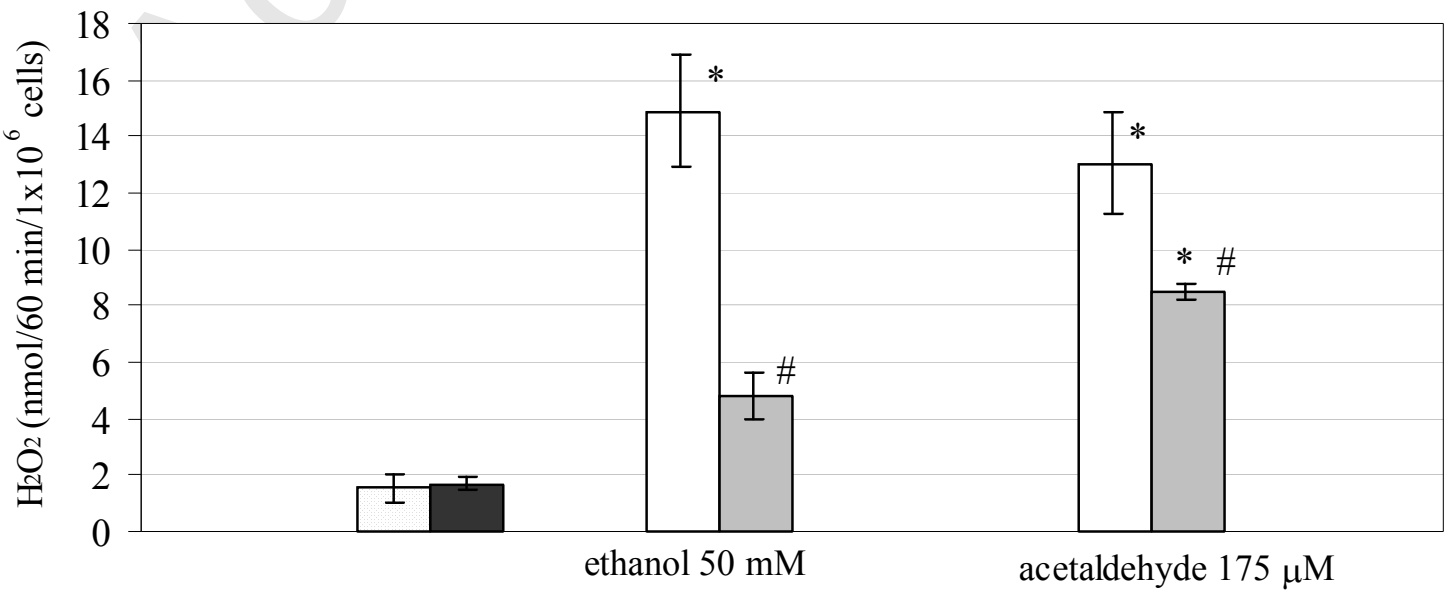

ethanol/acetaldehyde

++
$-\quad+$

$\begin{array}{ll}+ & + \\ - & +\end{array}$ 
Fig. 3 A
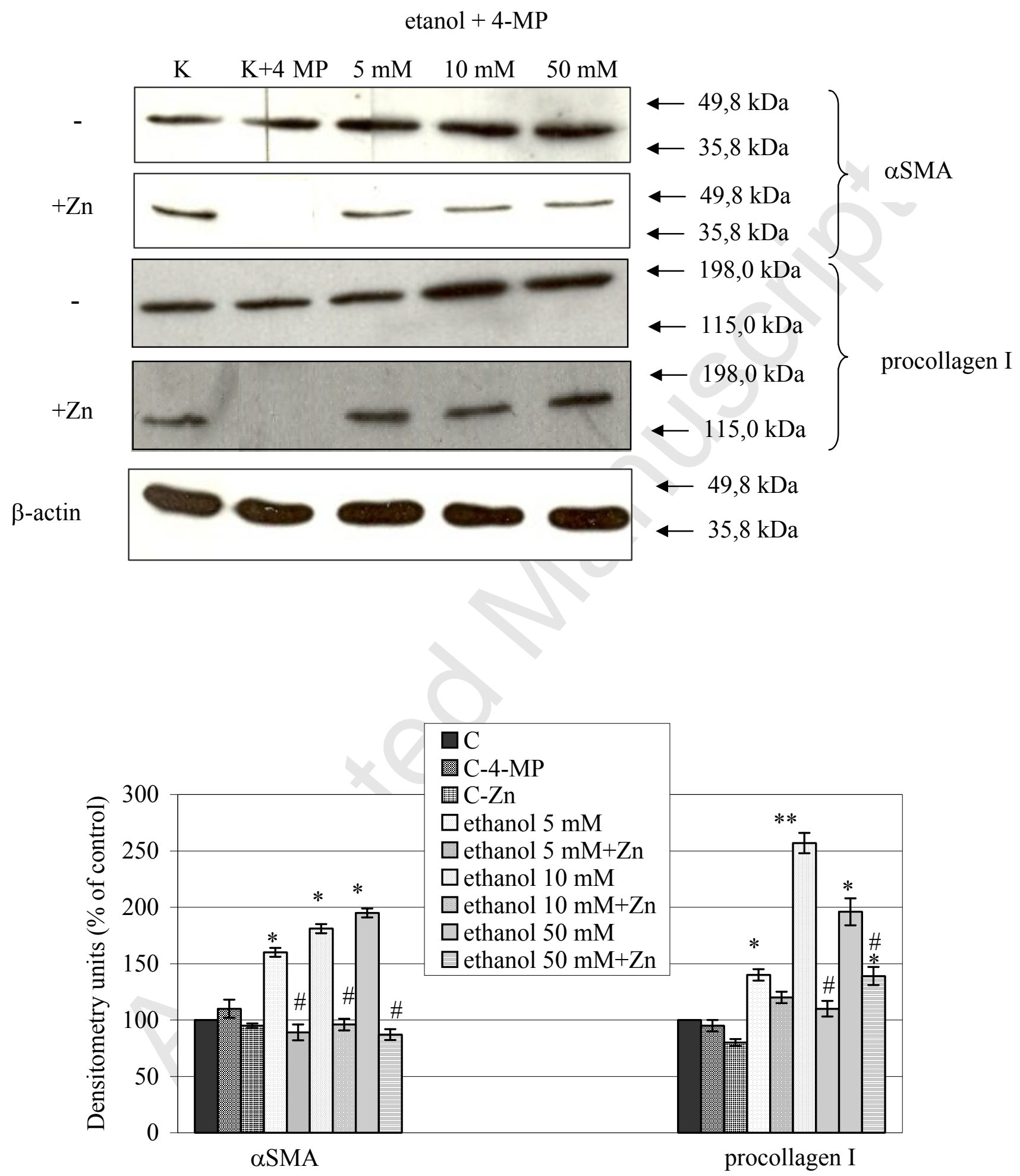
Fig. 3 B
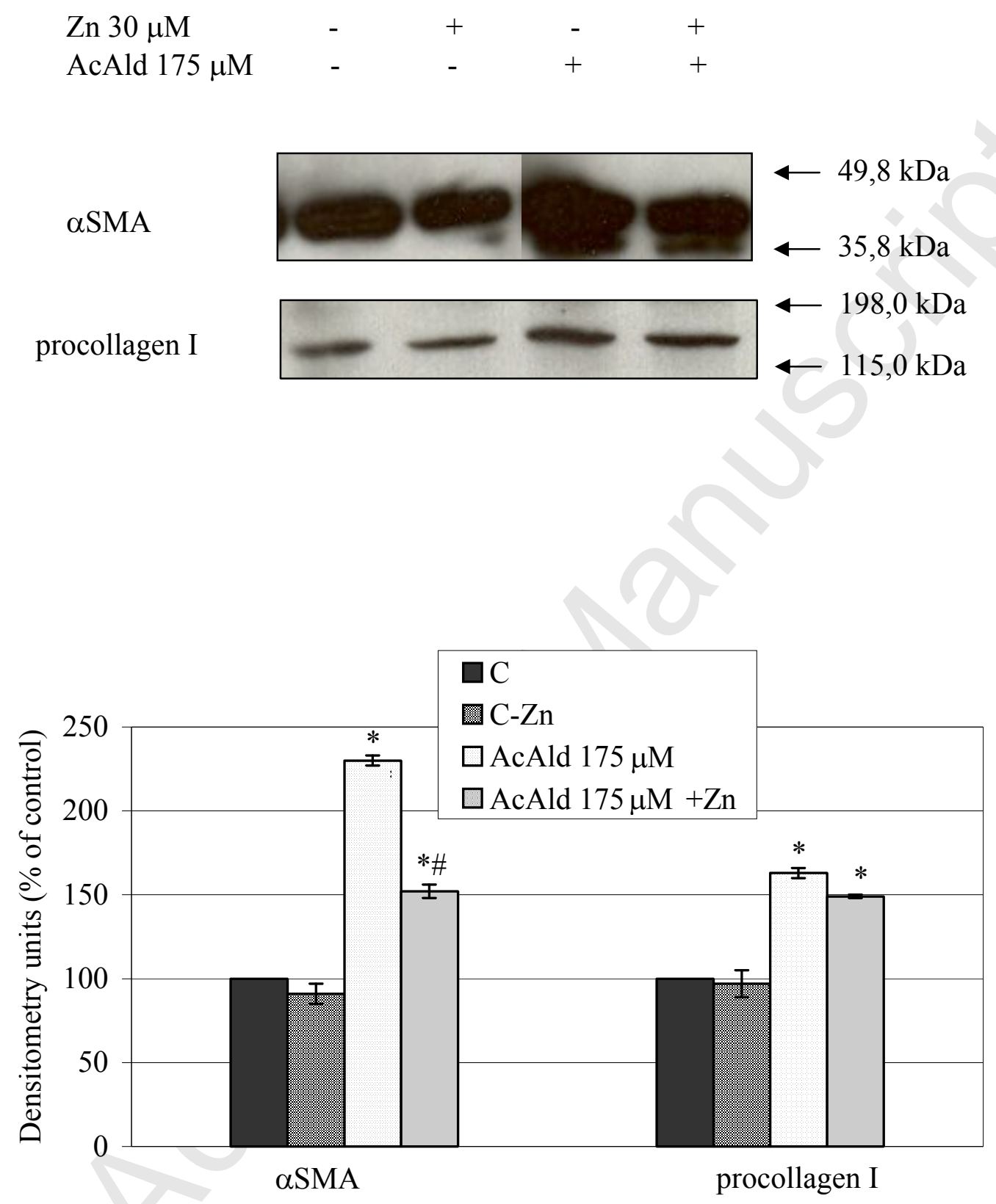
Fig. 4 A

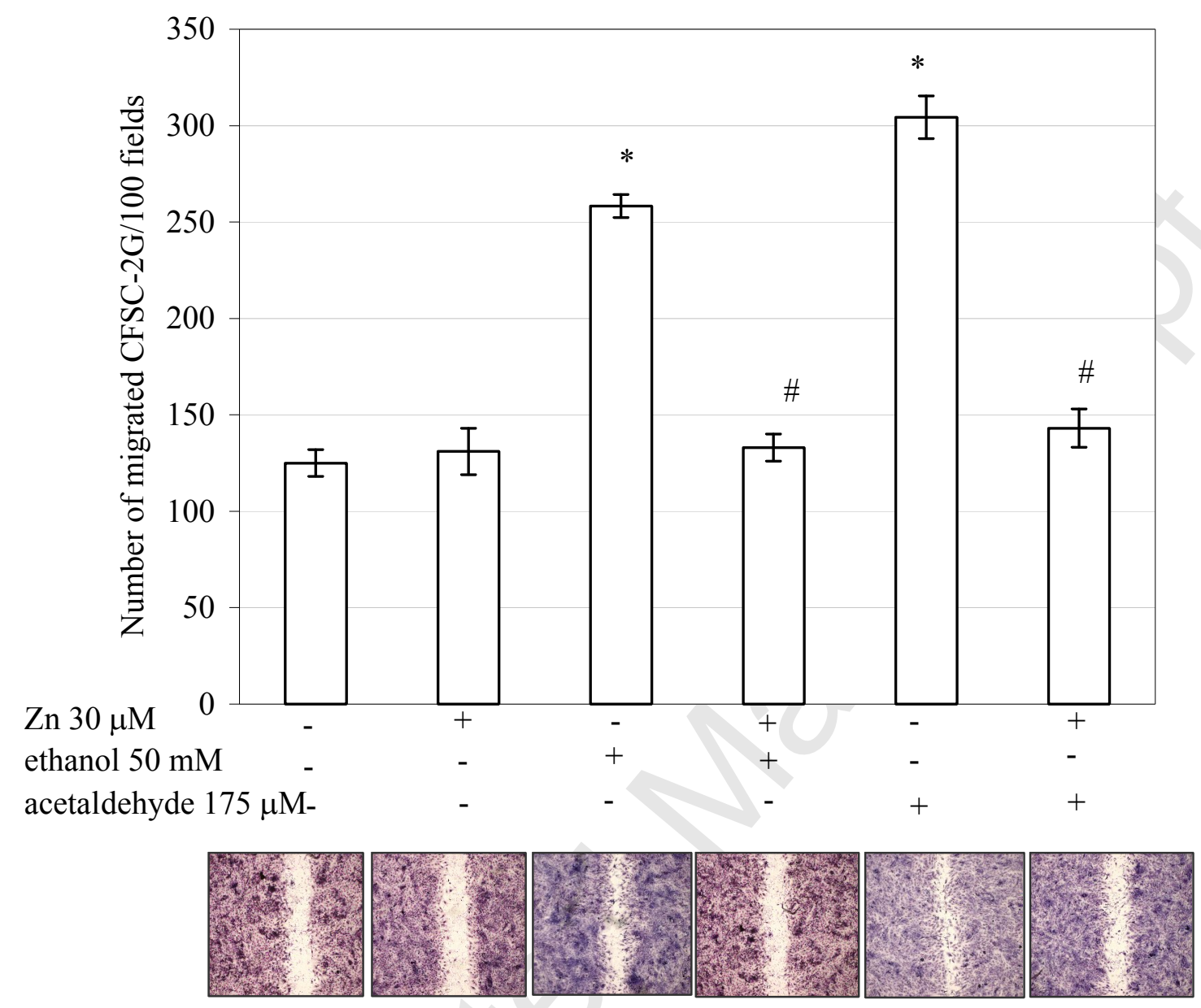


Fig. 4 B

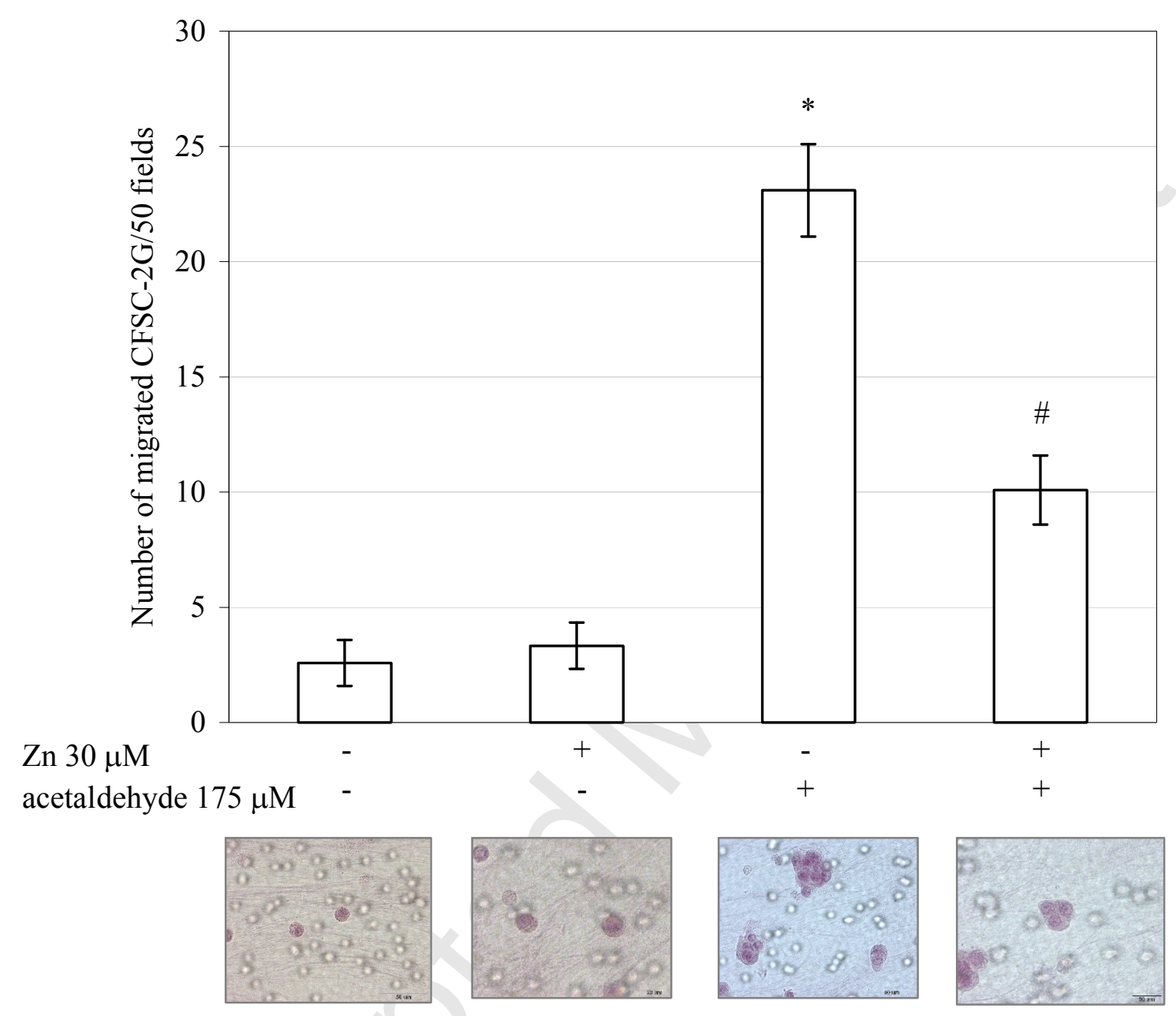


Fig. 5

A

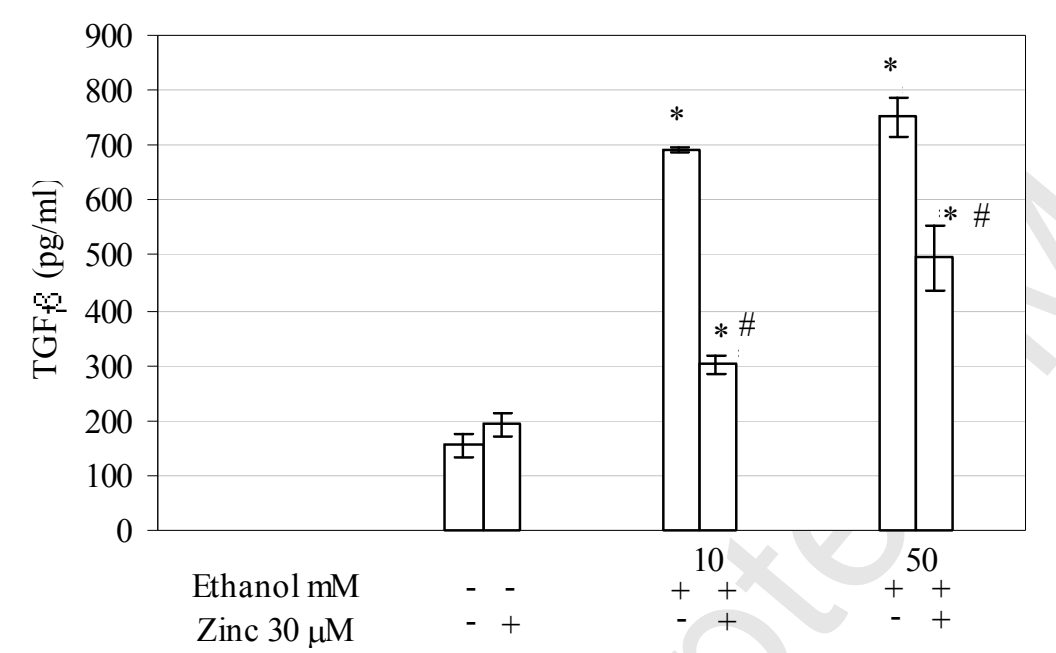

C

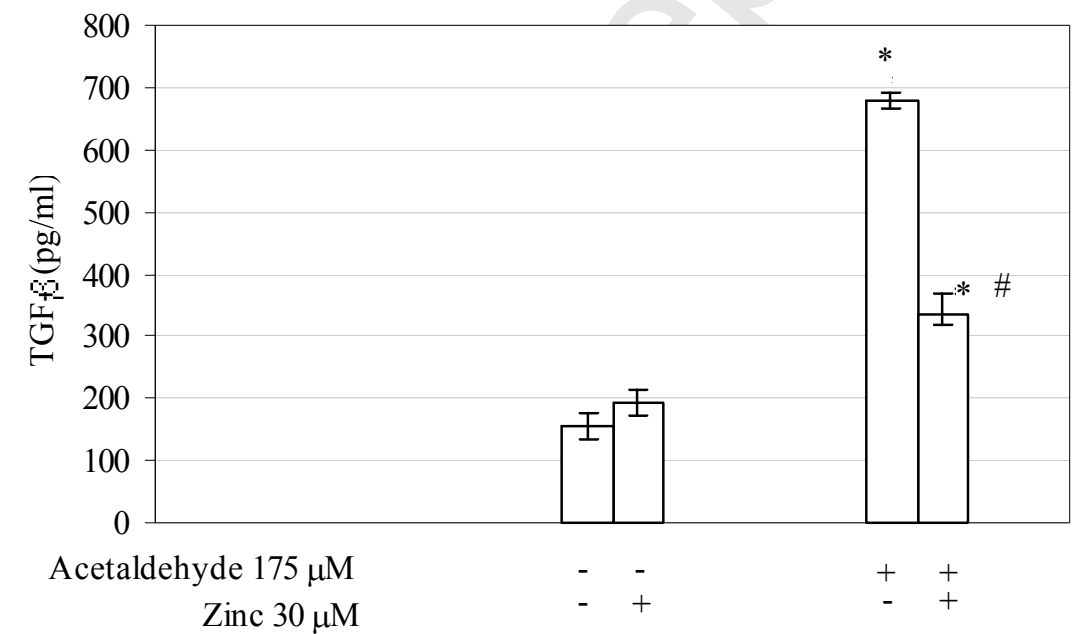

B

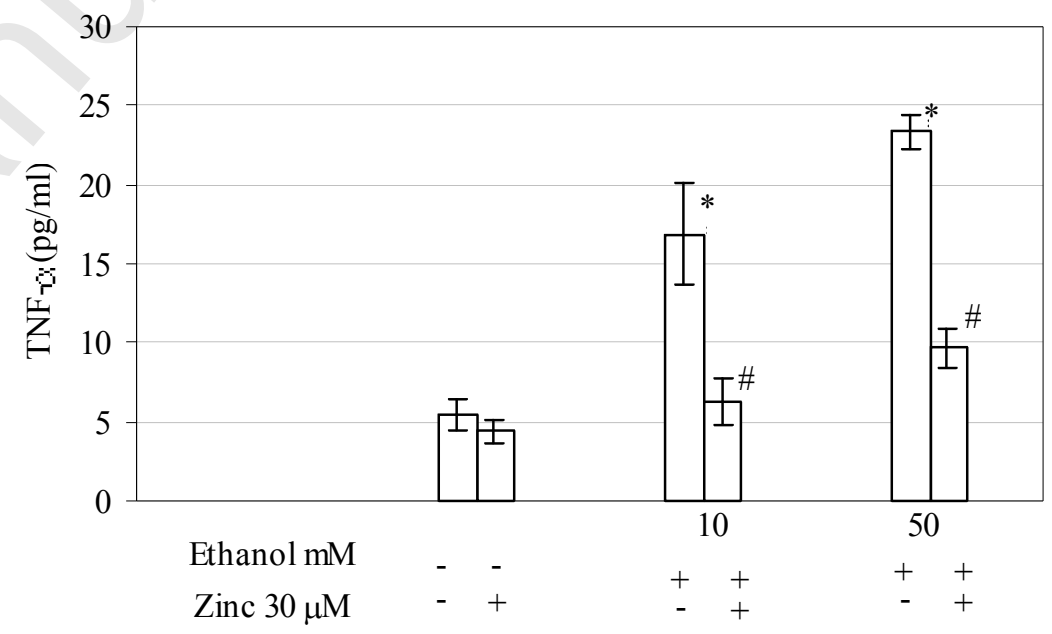

D

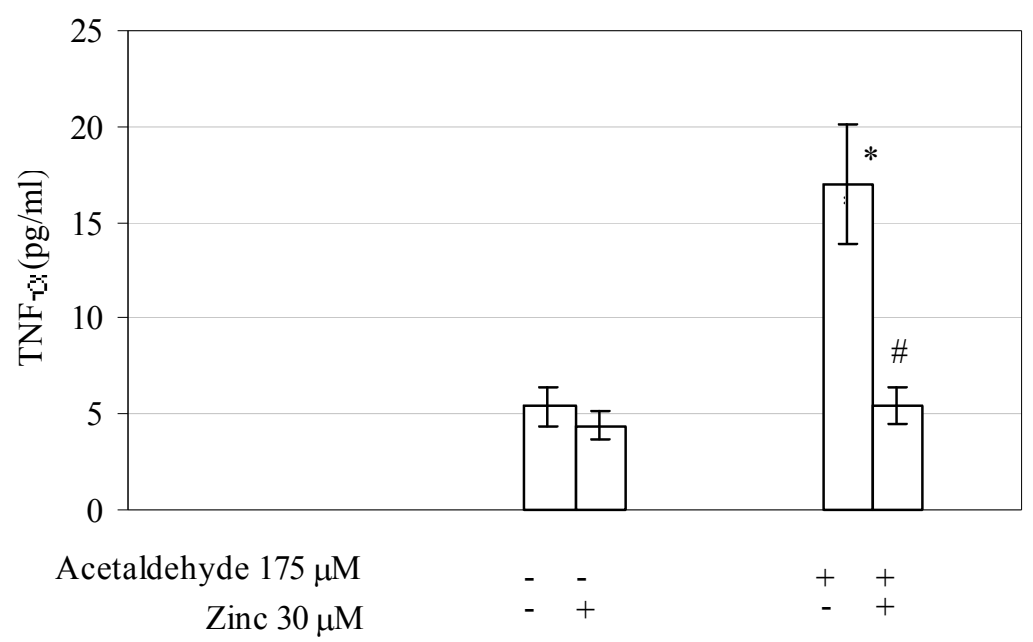


Fig. 6

A

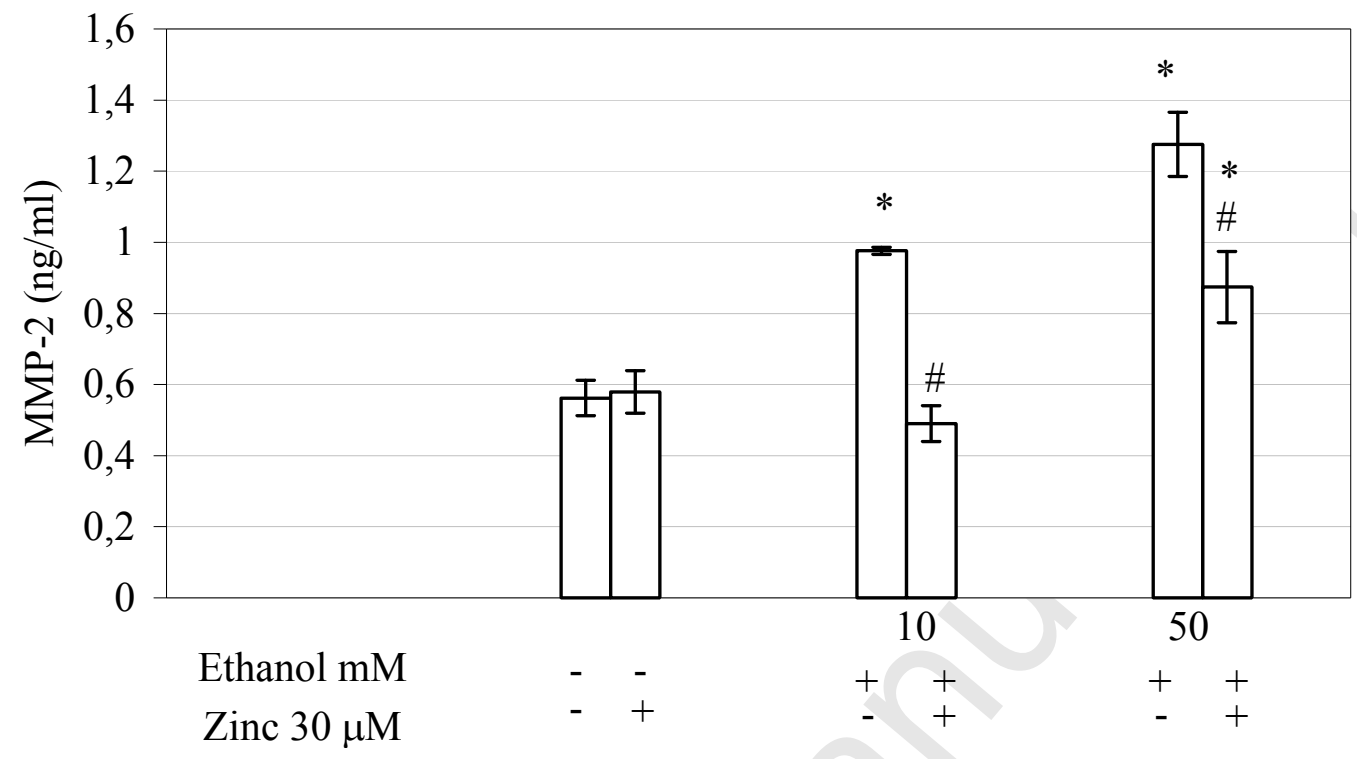

B

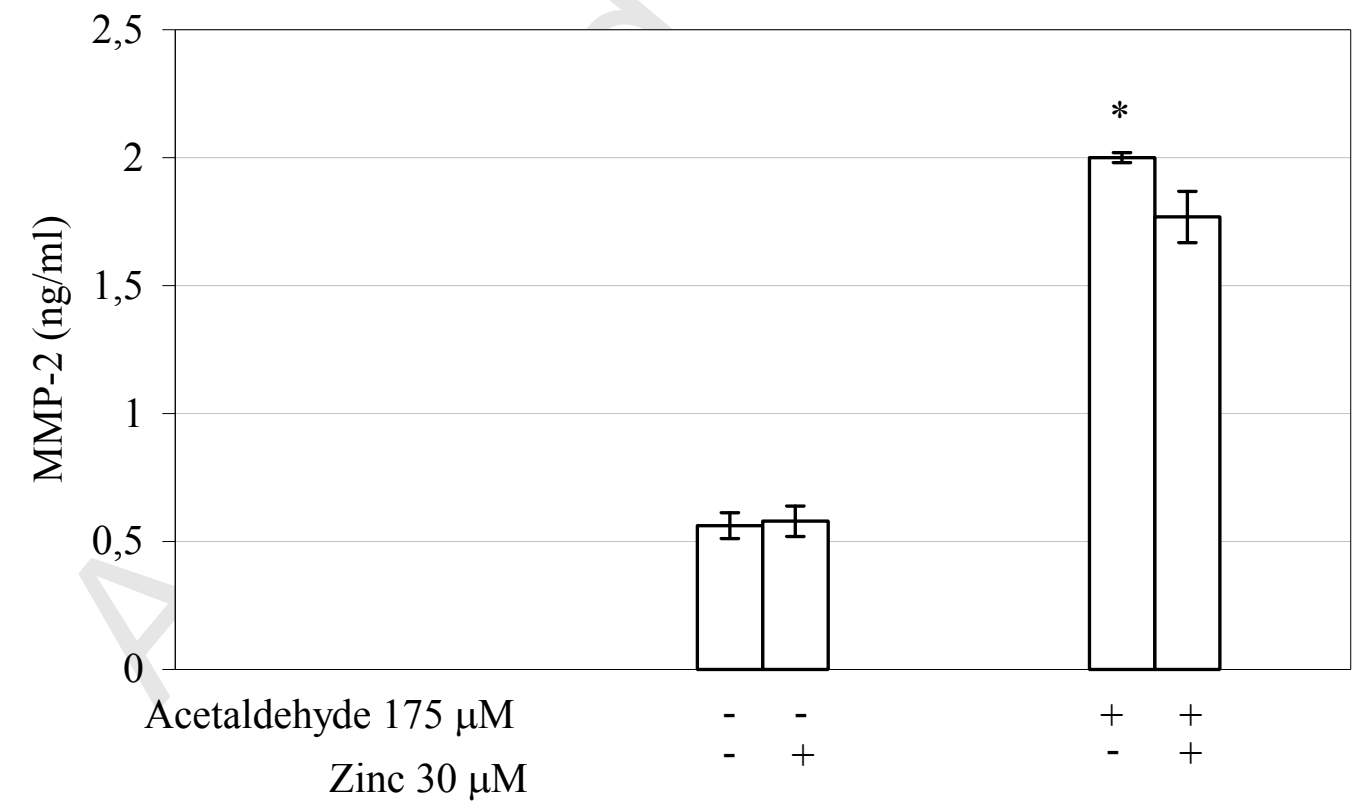


Fig. 7 A
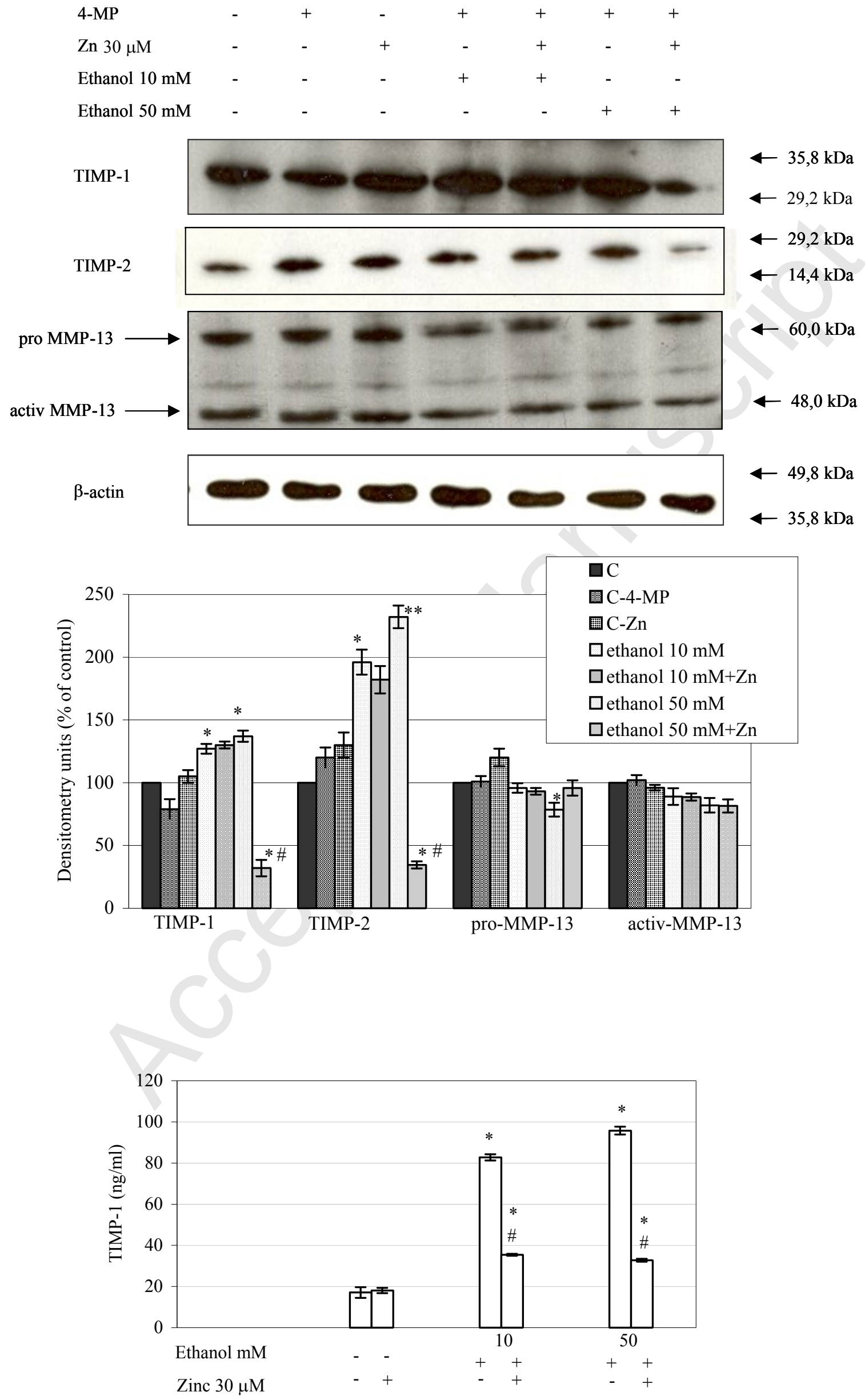
Fig. 7 B

Zn $30 \mu \mathrm{M}$

AcAld $175 \mu \mathrm{M}$

TIMP-1

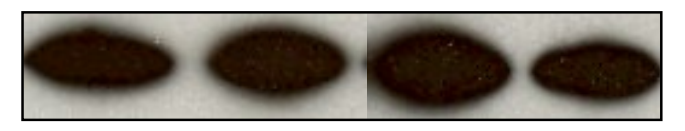

$\leftarrow 35,8 \mathrm{kDa}$

$\longleftarrow 29,2 \mathrm{kDa}$

TIMP-2

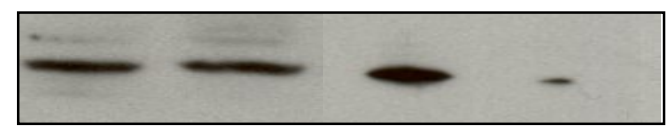

$\leftarrow 29,2 \mathrm{kDa}$

$\leftarrow 14,4 \mathrm{kDa}$

pro- $\longrightarrow$

MMP-13

activ- $\longrightarrow$

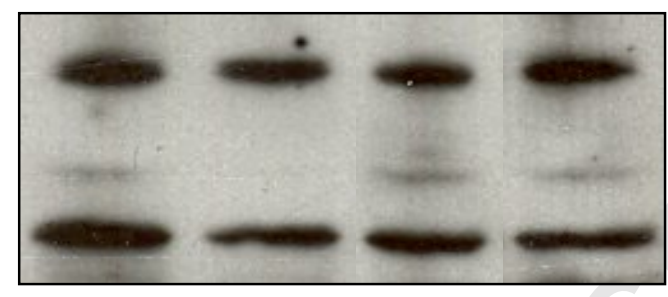

$\longleftarrow 60,0 \mathrm{kDa}$

$\beta$-actin
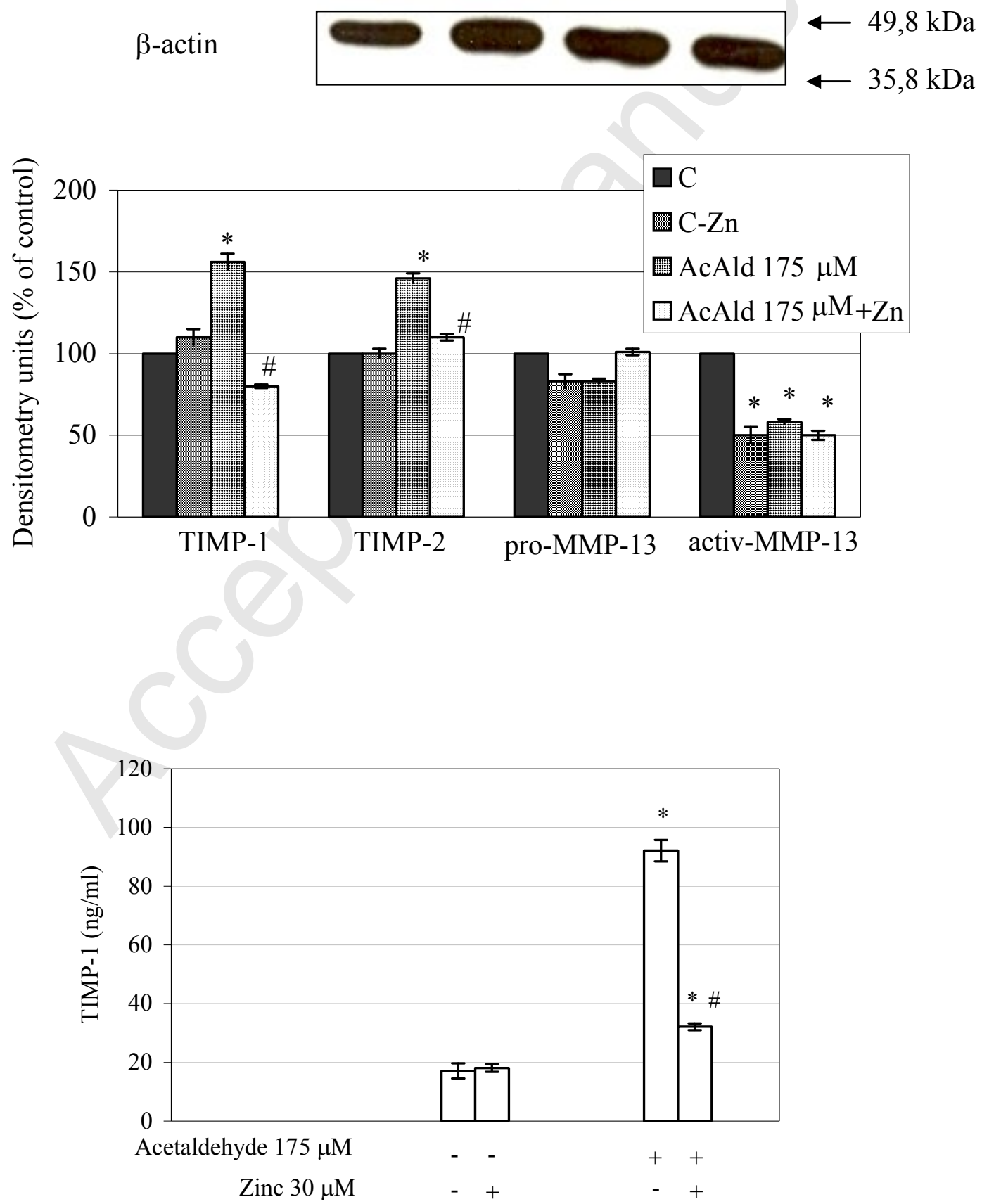
Fig. 8 A

$\begin{array}{llllll}\text { 4-MP } & - & + & - & - & - \\ \text { Zn } 30 \mu \mathrm{M} & - & - & + & - & + \\ \text { Et } 50 \mathrm{mM} & - & - & - & + & +\end{array}$

phospho NFкB

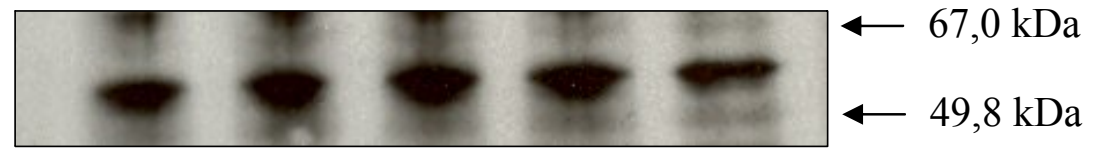

total NFאB

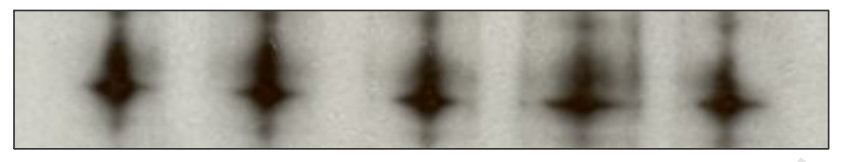

$\longleftarrow 67,0 \mathrm{kDa}$

$\longleftarrow 49,8 \mathrm{kDa}$

phospho IкB $\alpha$

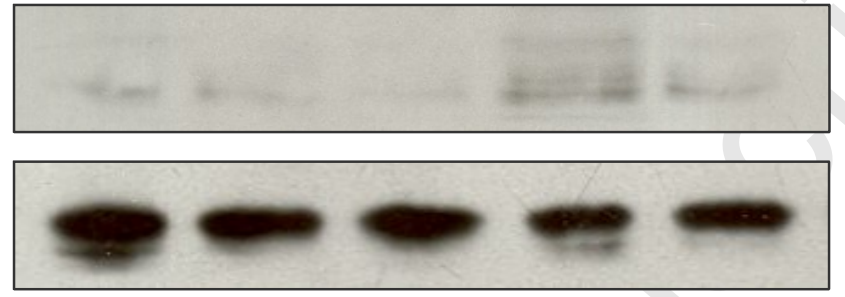

$\longleftarrow 49,8 \mathrm{kDa}$

$\longleftarrow 35,8 \mathrm{kDa}$

total $\mathrm{I} \kappa \mathrm{B} \alpha$

phospho JNK

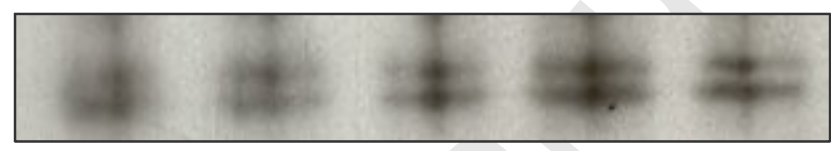

$\longleftarrow 49,8 \mathrm{kDa}$

$\longleftarrow 35,8 \mathrm{kDa}$

total JNK

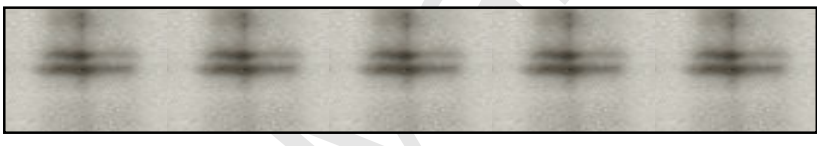

$\longleftarrow 67,0 \mathrm{kDa}$

$\longleftarrow 35,8 \mathrm{kDa}$

$\longleftarrow 67,0 \mathrm{kDa}$

$\longleftarrow 35,8 \mathrm{kDa}$

phospho p38

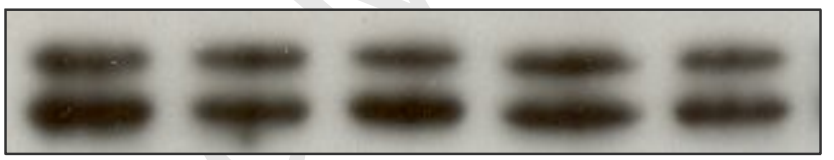

$\longleftarrow 49,8 \mathrm{kDa}$

$\longleftarrow 35,8 \mathrm{kDa}$

total p38

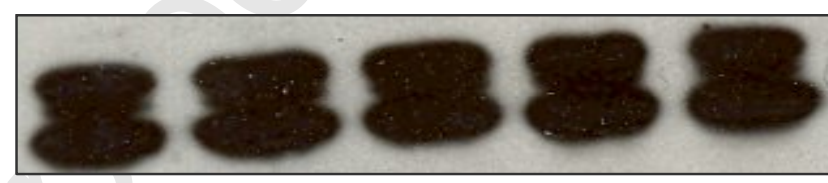

$\longleftarrow 49,8 \mathrm{kDa}$

$\longleftarrow 35,8 \mathrm{kDa}$

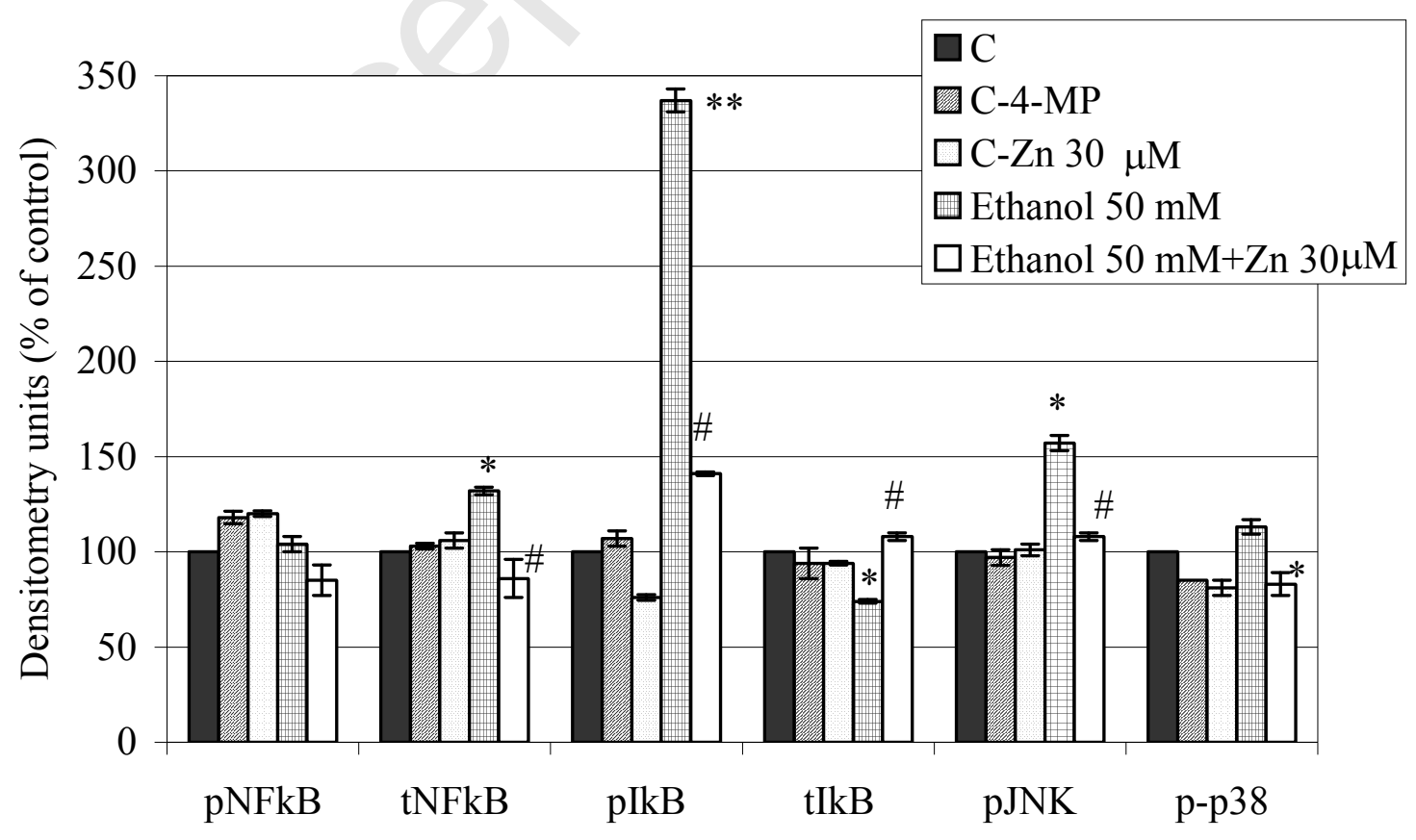


Fig. 8 B
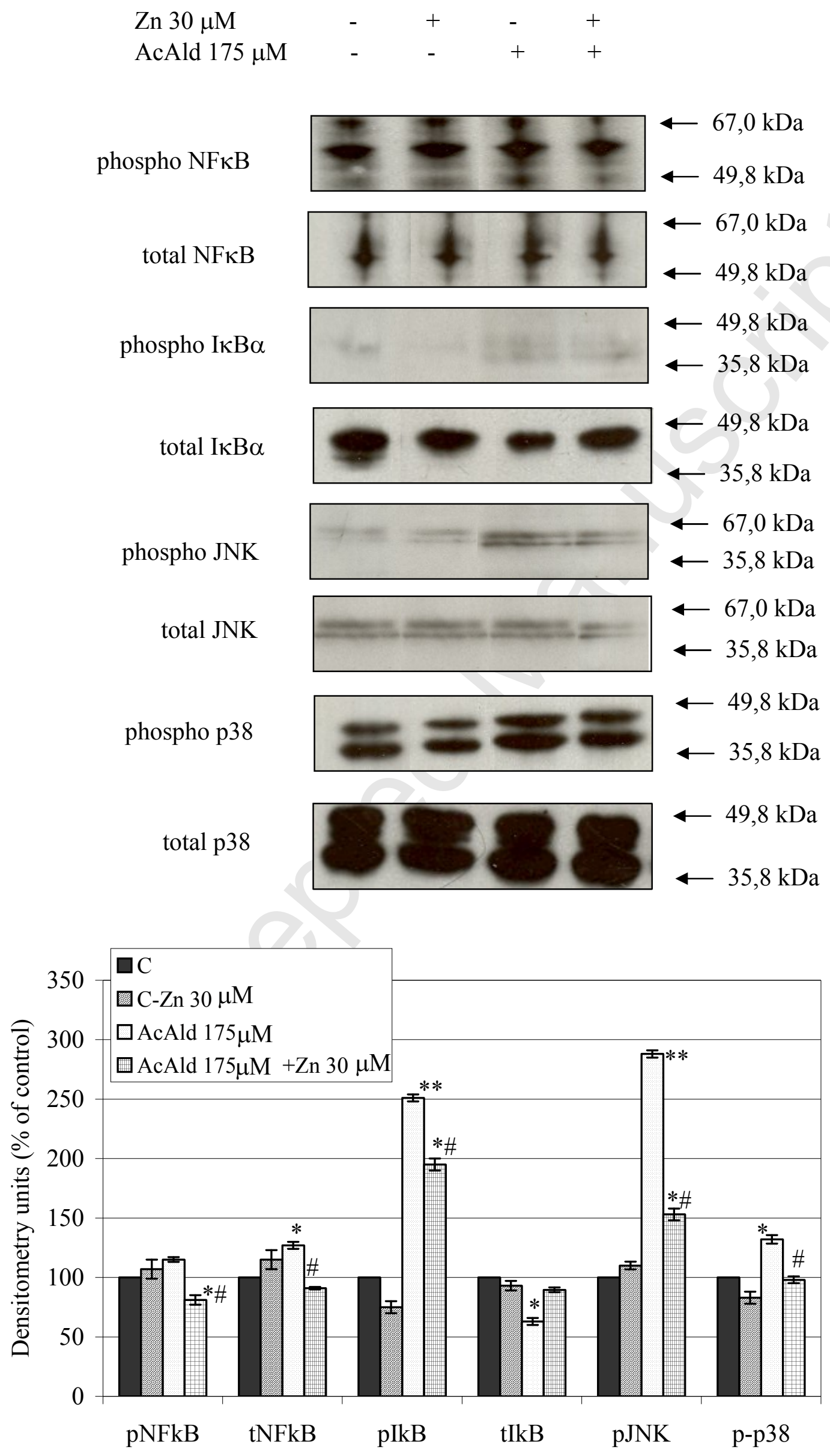
Fig. 9 A
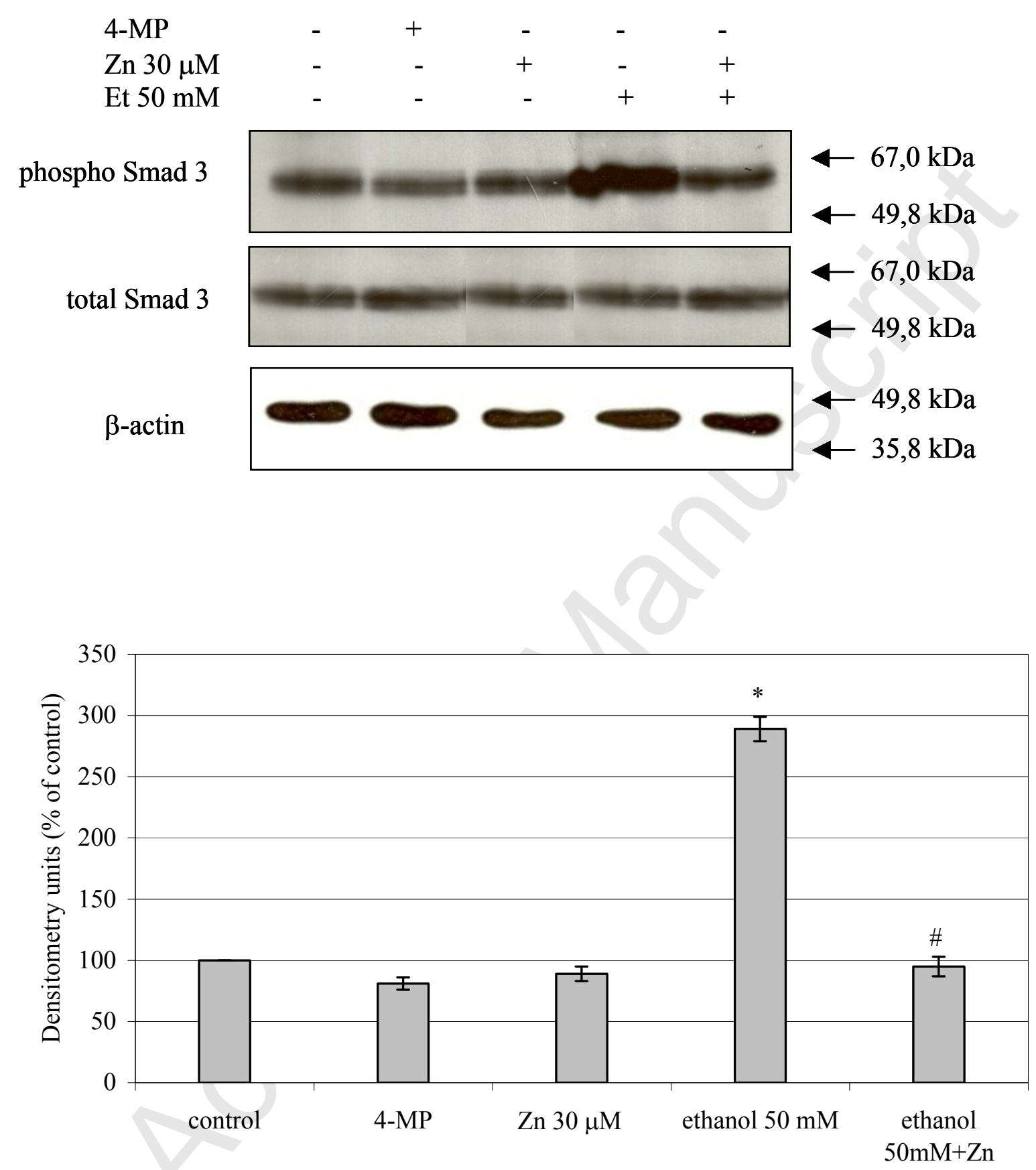
Fig. 9 B
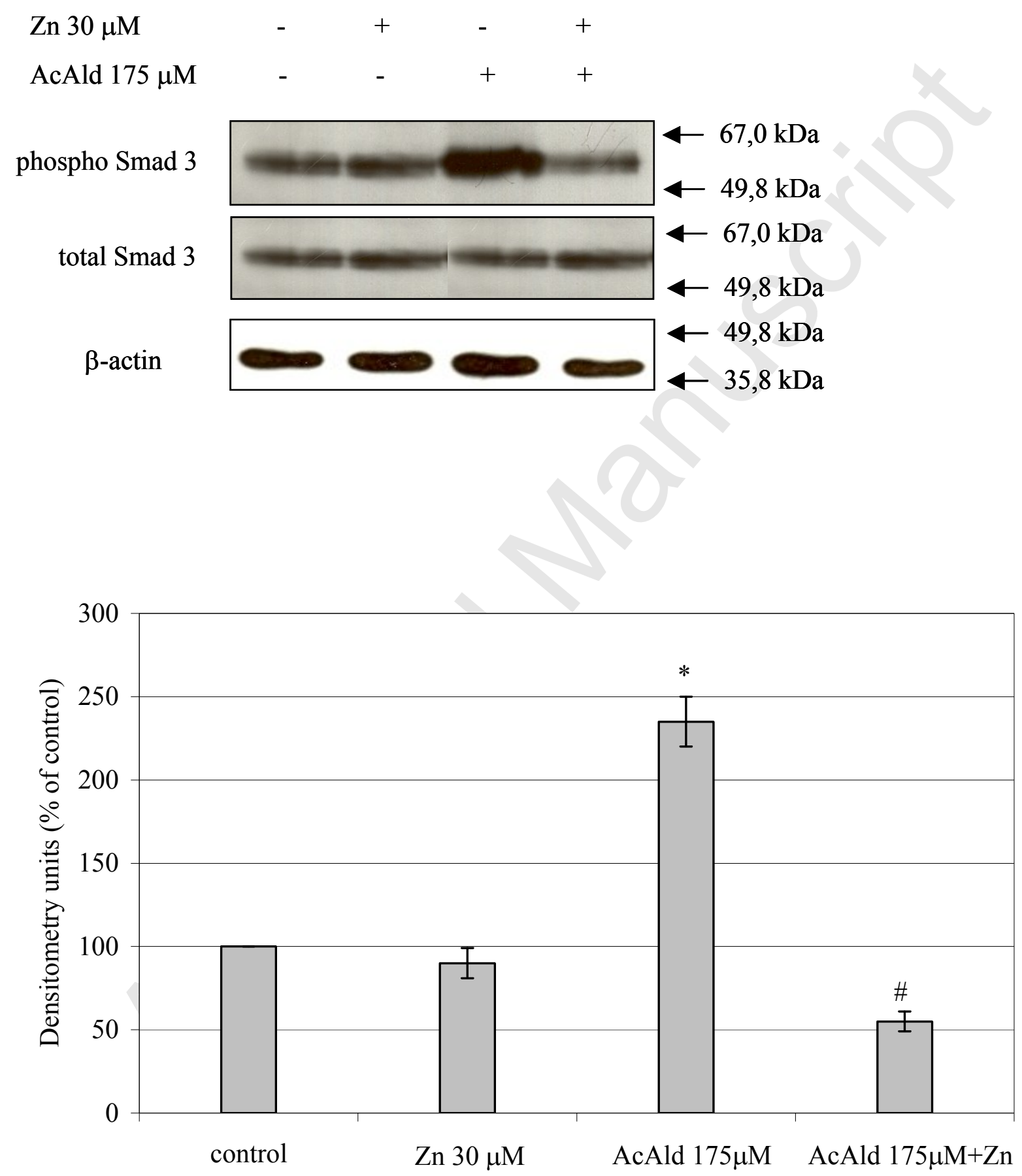
Fig $10 \quad$ A
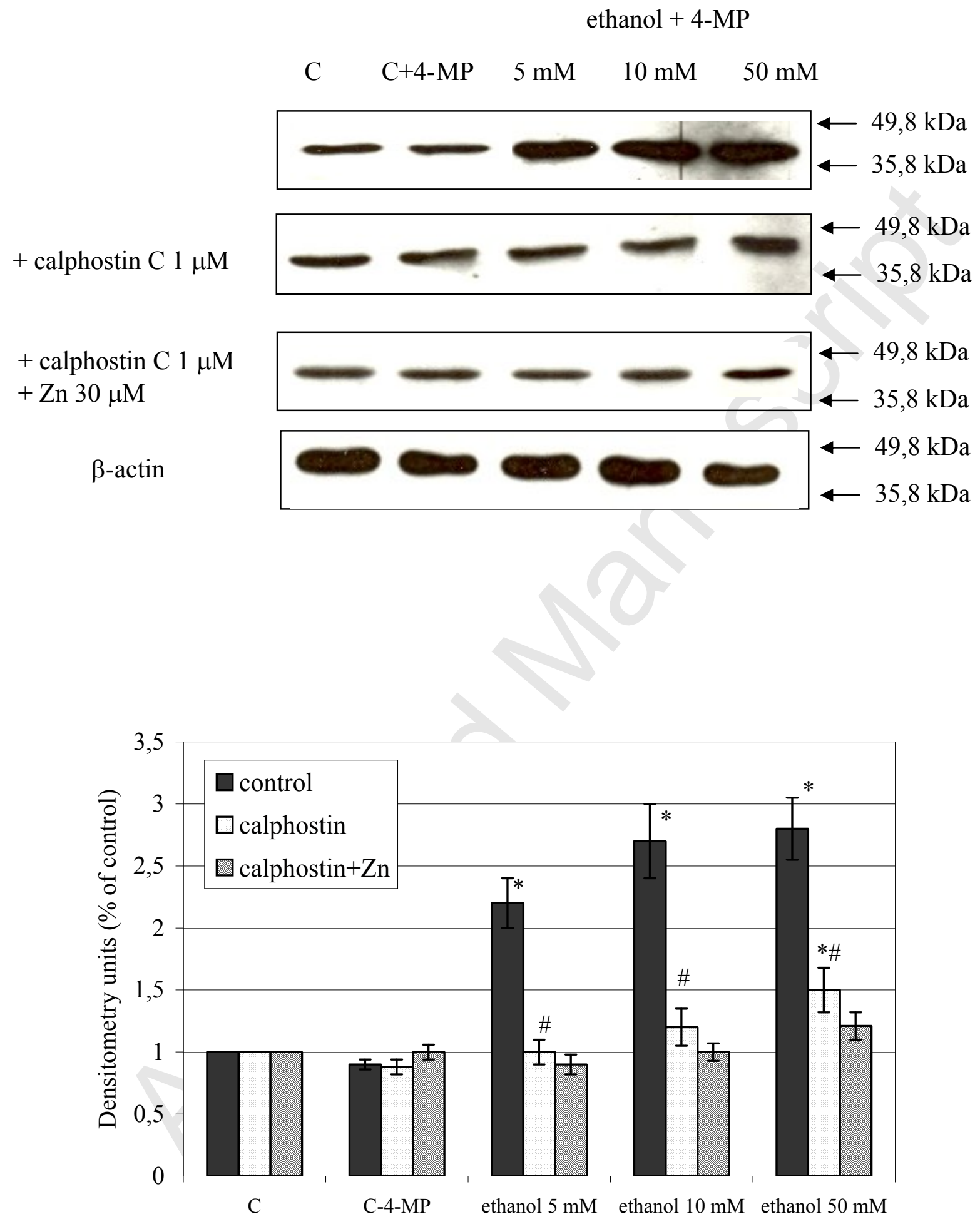
Fig. $10 \quad$ B
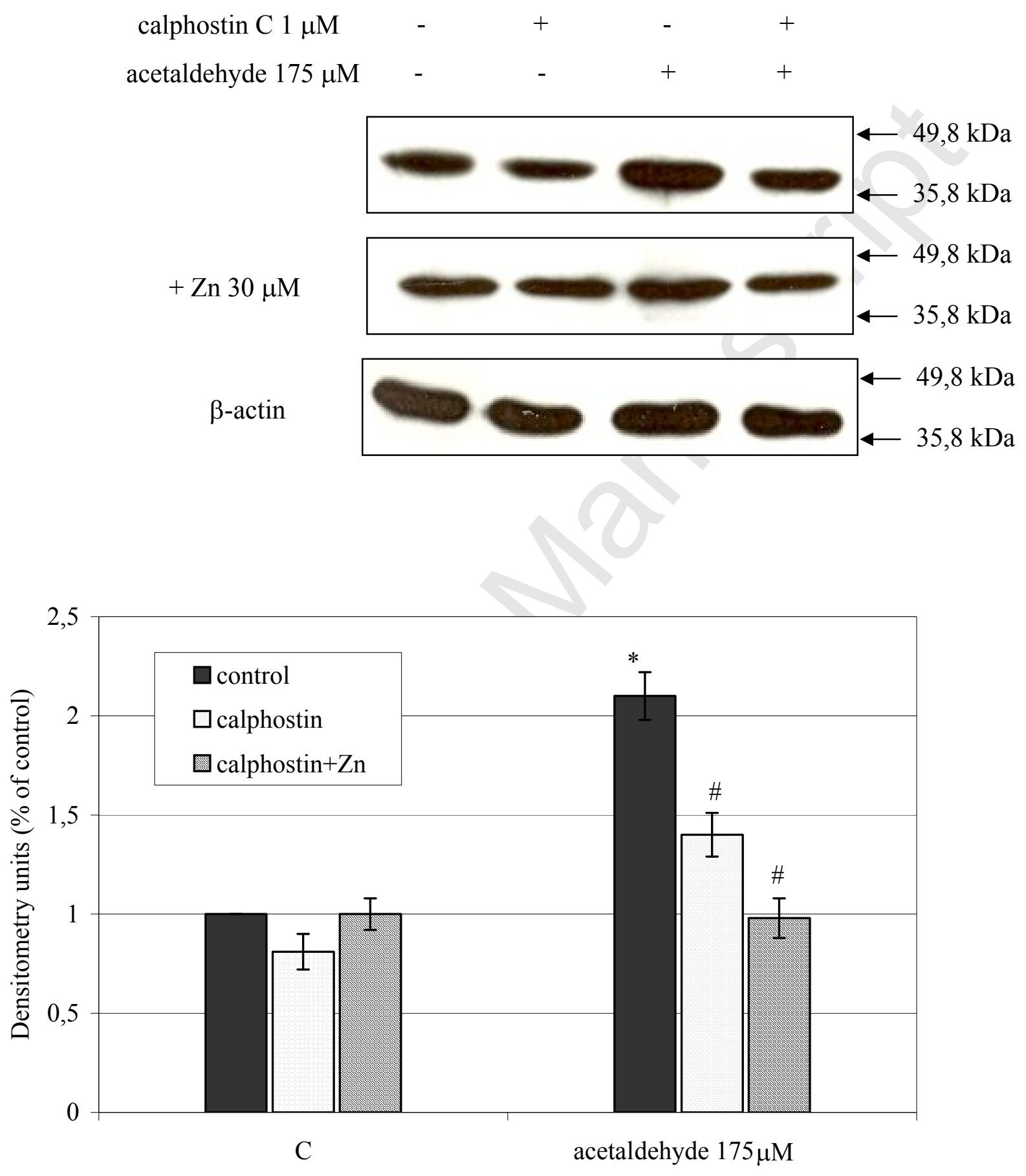


\section{Fig. 11}

Possible mechanisms for the antifibrotic effects of $\mathrm{ZnCl}_{2}$ on hepatic stellate cells.

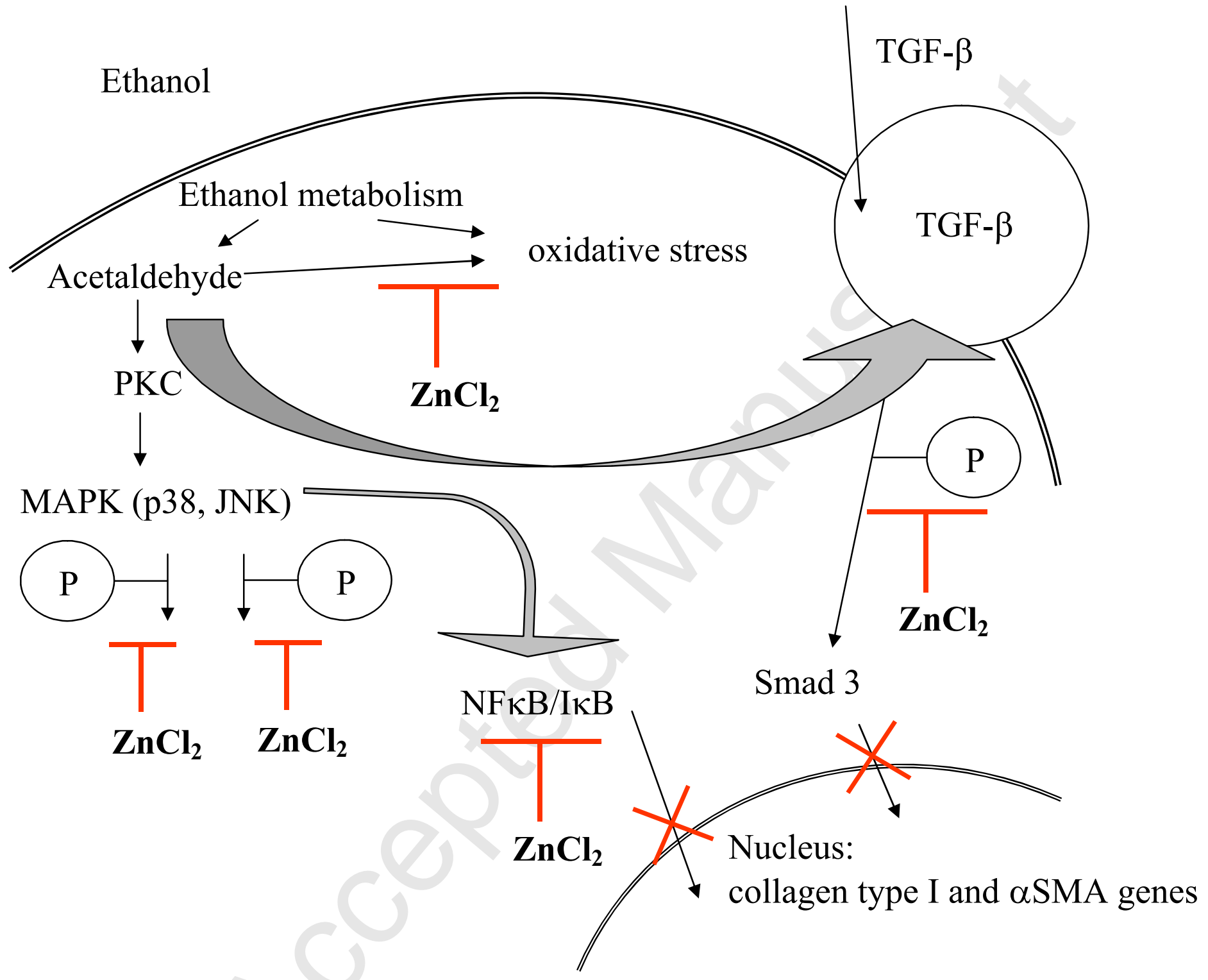


Possible mechanisms for the antifibrotic effects of zinc chloride on hepatic stellate cells.

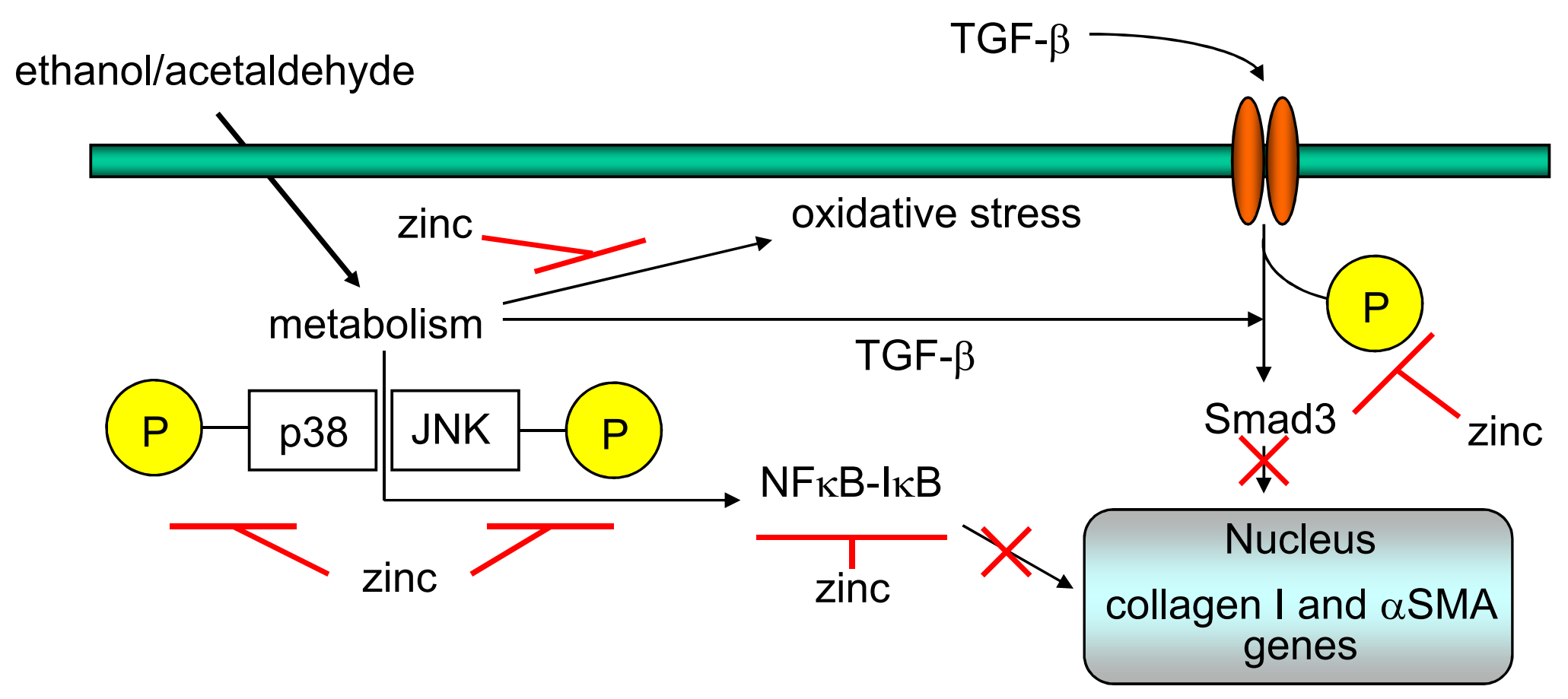

